\title{
Long-range transport and mixing of aerosol sources during the 2013 North American biomass burning episode: analysis of multiple lidar observations in the western Mediterranean basin
}

\author{
Gerard Ancellet $^{1}$, Jacques Pelon ${ }^{1}$, Julien Totems ${ }^{2}$, Patrick Chazette ${ }^{2}$, Ariane Bazureau ${ }^{1}$, Michaël Sicard ${ }^{3}$, \\ Tatiana Di Iorio ${ }^{4}$, Francois Dulac ${ }^{2}$, and Marc Mallet ${ }^{5}$ \\ ${ }^{1}$ LATMOS/IPSL, UPMC Univ. Paris 06 Sorbonne Universités, UVSQ, CNRS, Paris, France \\ ${ }^{2}$ LSCE, Laboratoire des sciences du Climat et de l'Environnement, CEA, Université Versailles St-Quentin, CNRS/INSU, \\ Gif-sur-Yvette, France \\ ${ }^{3}$ RSLab/CTE-CRAE-IEEC, Universitat Politècnica de Catalunya, Barcelona, Spain \\ ${ }^{4}$ ENEA, Agenzia nazionale per le nuove tecnologie, l'energia e lo sviluppo economico sostenibile, Rome, Italy \\ ${ }^{5}$ Laboratoire d'Aérologie, Université Paul Sabatier, CNRS/INSU, Toulouse, France \\ Correspondence to: Gerard Ancellet (gerard.ancellet@latmos.ipsl.fr)
}

Received: 9 October 2015 - Published in Atmos. Chem. Phys. Discuss.: 18 November 2015

Revised: 21 January 2016 - Accepted: 22 March 2016 - Published: 15 April 2016

\begin{abstract}
Long-range transport of biomass burning (BB) aerosols between North America and the Mediterranean region took place in June 2013. A large number of groundbased and airborne lidar measurements were deployed in the western Mediterranean during the Chemistry-AeRosol Mediterranean EXperiment (ChArMEx) intensive observation period. A detailed analysis of the potential North American aerosol sources is conducted including the assessment of their transport to Europe using forward simulations of the FLEXPART Lagrangian particle dispersion model initialized using satellite observations by MODIS and CALIOP. The three-dimensional structure of the aerosol distribution in the ChArMEx domain observed by the ground-based lidars (Minorca, Barcelona and Lampedusa), a Falcon-20 aircraft flight and three CALIOP tracks, agrees very well with the model simulation of the three major sources considered in this work: Canadian and Colorado fires, a dust storm from western US and the contribution of Saharan dust streamers advected from the North Atlantic trade wind region into the westerlies region. Four aerosol types were identified using the optical properties of the observed aerosol layers (aerosol depolarization ratio, lidar ratio) and the transport model analysis of the contribution of each aerosol source: (i) pure BB layer, (ii) weakly dusty $\mathrm{BB}$, (iii) significant mixture of $\mathrm{BB}$ and dust transported from the trade wind region, and (iv) the outflow of Saharan dust by the subtropical jet and not mixed
\end{abstract}

with $\mathrm{BB}$ aerosol. The contribution of the Canadian fires is the major aerosol source during this episode while mixing of dust and BB is only significant at an altitude above $5 \mathrm{~km}$. The mixing corresponds to a $20-30 \%$ dust contribution in the total aerosol backscatter. The comparison with the MODIS aerosol optical depth horizontal distribution during this episode over the western Mediterranean Sea shows that the Canadian fire contributions were as large as the direct northward dust outflow from Sahara.

\section{Introduction}

Forest fires are a significant source of tropospheric aerosol particles at northern latitudes in spring and summer (Generoso et al., 2003; Warneke et al., 2009), and many studies project higher temperatures and longer growing season (Flannigan et al., 2009; Liu et al., 2014). The focus of biomass burning emission impact on the atmospheric composition is often on the effect of these fires on the aerosol distribution in North America and Siberia (Eck et al., 2009; Warneke et al., 2010). Long-range transport of biomass burning plumes has been also recognized as a significant source of aerosol in the mid-latitude free troposphere over Europe (Müller et al., 2005; Fiebig et al., 2003; Sciare et al., 2008; Adler et al., 2011). Air mass aging related to long-range 
transport also leads to aerosol optical and chemical properties different from results obtained when looking at observations close to the fire region (Liousse et al., 1995; Müller et al., 2007; Bougiatioti et al., 2014). As an example, the absorbing efficiency in the visible spectral range is known to significantly increase in case of internally mixed BC (coating with secondary compounds) compared to externally mixed BC (Schnaiter et al., 2005). So far little attention has been paid to the frequent mixing of dust and biomass burning (BB) aerosol occurring during their transatlantic long-range transport while lidar data analysis has shown that such a mixing will likely modify the extinction to backscatter ratio often called lidar ratio (LR) and then the aerosol optical depth (AOD) (Cattrall et al., 2005; Gross et al., 2011). Results of Paris et al. (2010) also show that the solubility of iron is enhanced by the mixing with biomass burning aerosols, while aerosol deposition may influence the rate of nitrogen fixation by microorganisms, and subsequently the global carbon cycle (Guieu et al., 2014). Although episodic, such longrange transport of smoke aerosols over the Mediterranean can also impact the regional energy budget by changing the distribution of solar energy. Indeed, for an aged BB plume, Formenti et al. (2002) report a net shortwave radiative forcing over the sea (daytime average) up to $-64 \mathrm{~W} \mathrm{~m}^{-2}$, at the surface and up to $-22 \mathrm{~W} \mathrm{~m}^{-2}$, at the top of the atmosphere (for an AOD of 0.40 at $550 \mathrm{~nm}$ ). The large concentration of absorbing material (BC particles) within smoke plumes leads to significant absorption of solar radiations within the atmospheric layer where smoke resides, which could perturb the relative humidity and temperature vertical profiles. In the framework of the Chemistry-Aerosol Mediterranean Experiment/Aerosol Direct Radiative Impact in the Mediterranean (ChArMEx/ADRIMED) experimental campaign, many aerosol lidar and aircraft measurements were made in June-July 2013 in the Mediterranean region during a case of intense biomass burning transport from North America to Europe (Mallet et al., 2016; Chazette et al., 2016; Pelon et al., 2015). Only a few studies report such long-range transport observations from North America to Europe (Forster et al., 2001; Petzold et al., 2007) or even the eastern Mediterranean (Formenti et al., 2002).

The purpose of this paper is to analyze the transatlantic long-range transport of $\mathrm{BB}$ and dust aerosol sources from North America during this period. The context of our study is described in Sect. 2 by describing the main characteristics of the summer 2013 BB episode in North America and the observation network considered for the analysis of the aerosol distribution in the Mediterranean region. The aerosol sources are identified using satellite observations, and the transport of dust or BB plumes is calculated with the FLEXPART Lagrangian model (see Sect. 3). The aerosol lidar observations are discussed in Sect. 4, where the contribution of the different aerosol sources is assessed using the comparison of the spatial distribution of the layers with the FLEXPART model simulations (forward from the source regions and backward to calculate the potential emission sensitivity for each observed aerosol layers). The mixing between dust and BB plumes is mainly derived from the analysis of the aerosol layer optical properties. The Minorca and aircraft lidar observations during ChArMEx are thoroughly described in a companion paper (Chazette et al., 2016) submitted with this paper and in a paper in preparation by Pelon et al. (2016).

\section{Context}

\subsection{The 2013 North American biomass burning period}

June 2013 was on the drier side in the US High Plains region with most areas receiving less than $70 \%$ of normal precipitation. It was especially dry for most of Colorado and Wyoming, which received less than $50 \%$ of normal precipitation, and many locations in the western areas of those states received little to no precipitation. As a consequence many fires took place in North America. Fire started in the state of Colorado on 10 June and lasted until 22 June 2013 (Colorado HSEM, 2013). Two large fires in southern Colorado even produced pyrocumulonimbus clouds and very large smoke plumes on 19 and 20 June 2013 in the West Fork Complex and in the East Peak.

In Canada there were also many fires (334) during the period 13 to 26 June 2013 burning 632000 ha. The seasonal fire occurrence was below average while the area burned was more than twice the 10-year average, due to large fires burning in Québec. The majority of fires were spread between Manitoba, Alberta, Yukon and Northwest Territories, and Québec, while $75 \%$ of the area burned was in Québec and $20 \%$ in Manitoba (CIFFC, 2013). The total amount of area burned was around 500000 ha for the period 12 to 25 June 2013 , i.e., more than twice the 10-year summer average for the same period. The eastern Canadian fires at 80 and $100^{\circ} \mathrm{W}$ took place during 4-6 days between 18 and 24 June while the fires west of $120^{\circ} \mathrm{W}$ took place during 2-3 days starting on 17 June in Alaska and 22 June in the Mackenzie Mountains.

\subsection{The 2013 Mediterranean lidar observation network}

During ChArMEx an intensive observation period took place in western Mediterranean region from 11 June to 5 July 2013 (SOP-1a) when airborne measurements were made by two aircraft (ATR42 and F20) and ground-based observations at four sites in Lampedusa, Corsica, Barcelona and Minorca (Mallet et al., 2016). During ChArMEx, aerosol backscatter vertical profiles were made by airborne and ground-based lidar systems, which provide a very good opportunity to characterize the vertical distribution of the North American BB plume over the Mediterranean region. The map of the ChArMEx lidar observation network is shown in Fig. 1. The Falcon 20 aircraft was equipped with an airborne lidar LNG (Pelon et al., 2002) providing attenuated backscatter vertical 
profiles at three wavelengths (1064, 532 and $355 \mathrm{~nm})$. It was based in Cagliari, Sardinia. The LNG lidar has been mainly used with a downward-looking mode. Two tracks have been made in late June during the passage of the BB plume over the western Mediterranean: a transect between Cagliari and Minorca on 27 June 2013 and a loop around Sicily on 28 June. Only the loop on 28 June is considered in this work because the 27 June data will be discussed in a future paper by Pelon et al. (2016) on the airborne observations during ChArMEx. The ground-based lidars are located in Minorca $\left(40^{\circ} \mathrm{N}, 4^{\circ} \mathrm{E}\right)$, Barcelona $\left(41.4^{\circ} \mathrm{N}, 2^{\circ} \mathrm{E}\right)$ and Lampedusa $\left(35.5^{\circ} \mathrm{N}, 12.5^{\circ} \mathrm{E}\right)$. The Minorca lidar works at $355 \mathrm{~nm}$, while the Barcelona and Lampedusa lidars measure the atmospheric backscatter signal at $532 \mathrm{~nm}$. The ground-based lidar systems are respectively described in Chazette et al. (2014), Kumar et al. (2011), and Di Iorio et al. (2009). The airborne lidar LNG was also run every morning in Cagliari $\left(39^{\circ} \mathrm{N}\right.$, $9^{\circ} \mathrm{W}$ ) from 24 to 30 June 2013 pointing upward from the surface. All the lidars can record also the depolarization ratio between the signal polarized parallel and perpendicular to the plane of the outgoing beam. For the ground-based lidar, the uncertainty on the aerosol depolarization ratio is of the order of $1-2 \%$ as explained in Chazette et al. (2012). For the airborne lidar LNG, the depolarization ratio is measured at $355 \mathrm{~nm}$ and it is calibrated on molecular scattering using a value of $1.5 \pm 0.3 \%$ for clean air, corresponding also to $1-$ $2 \%$ error on the aerosol depolarization ratio.

In addition to ground-based and airborne lidar, the observations of the spaceborne Cloud-Aerosol Lidar with Orthogonal Polarization (CALIOP) are known to be very useful to track aerosol plumes (Winker et al., 2009). Three CALIOP nighttime tracks shown in Fig. 1 on 27 and 28 June 2013 are ideally located above the ChArMEx area when the BB plume is expected over Europe.

\section{Aerosol sources and transport}

\subsection{Methodology}

Satellite remote sensing was considered for the BB aerosol source identifications: both Moderate Resolution Imaging Spectroradiometers (MODIS) on Terra and Aqua platforms, and CALIOP. The distribution of the fires was taken from the NASA Fire Information for Resource Management System (FIRMS), which provides the analysis of the MODIS hot spots in terms of fire radiative power (FRP) given in MW. Only fire areas with FRP $>0.8 \mathrm{GW}$ are included in this analysis. The MODIS $0.5 \mu \mathrm{m}$ AOD daily product is also considered to estimate the horizontal extent of BB plume when large AOD $>0.3$ is found near the spots with elevated FRP. Both MODIS instruments on Aqua and Terra are considered to derive the daily mean. The mean error on the MODIS AOD daily product is 0.03 with a root mean square error of 0.14 according to Ruiz-Arias et al. (2013). When a CALIOP

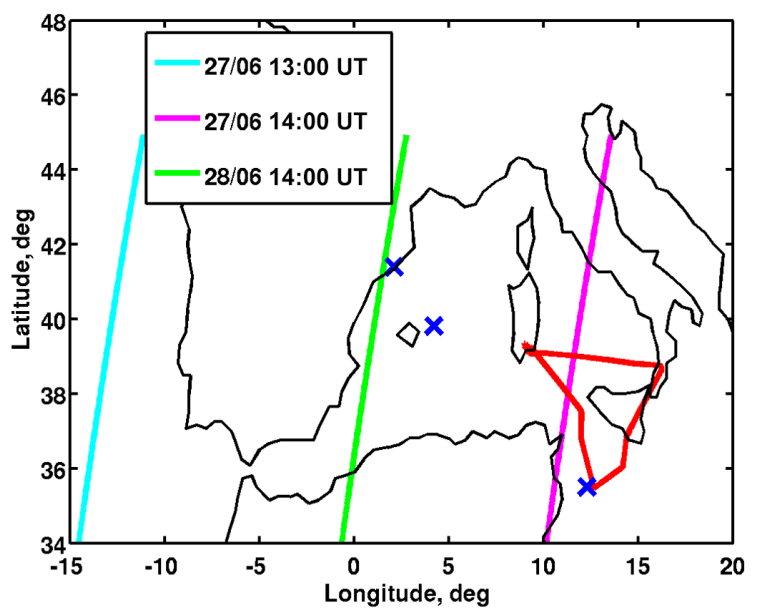

Figure 1. Map of the ChArMEx lidar observations. The colored vertical lines are the positions of the nighttime CALIOP tracks on 27 and 28 June 2013. The red thick line shows the loop followed by the Falcon 20 aircraft on 28 June 2013 from 13:00 to 15:00 UT, while the blue crosses are for the Minorca, Barcelona and Lampedusa ground-based lidar.

overpass is found near the MODIS BB plume, the lidar vertical cross section is used to specify the vertical extent of the MODIS BB plume.

For the dust aerosol sources, two main information sources were considered: (i) North American dust storms identified in the NAAPS (Navy Aerosol Analysis and Prediction System) Global Aerosol Model simulations and (ii) $0.5 \mu \mathrm{m}$ AOD anomalies from the MODIS daily products. AOD streamers transported from the tropical Atlantic belt of elevated $0.5 \mu \mathrm{m}$ AOD to the mid-latitudes are related to the transport of Saharan dust across the Atlantic. CALIOP overpasses near the AOD anomalies again provide the vertical extent of dust aerosol layers.

In this work we use the new CALIOP level-1 (L1) version 4.0 attenuated backscatter coefficients $\beta_{1064}$ and $\beta_{532}$ because they correspond to a better calibration of the lidar data. They are averaged using a $10 \mathrm{~km}$ horizontal resolution and a $60 \mathrm{~m}$ vertical resolution (Vaughan et al., 2012). Before making horizontal or vertical averaging, the initial $333 \mathrm{~m}$ horizontal resolution ( $1 \mathrm{~km}$ above the altitude $8.2 \mathrm{~km})$ is filtered to remove the cloud layer contribution (Winker et al., 2009). This cloud mask makes use of the version 3 level-2 (L2) cloud layer data products (Vaughan et al., 2009). Our scheme for distinguishing cloud and aerosol is described in Ancellet et al. (2014). Although the LR is available from the CALIOP version $3 \mathrm{~L} 2$ aerosol layer data products, it is often based on an aerosol classification algorithm (Omar et al., 2009). In our work the LR is recalculated by using the aerosol layer transmittance and the integrated attenuated backscatter in the aerosol layer following the method described in Young (1995). To reduce the error when using high-horizontal-resolution CALIOP profiles, $\beta_{532}$ is aver- 

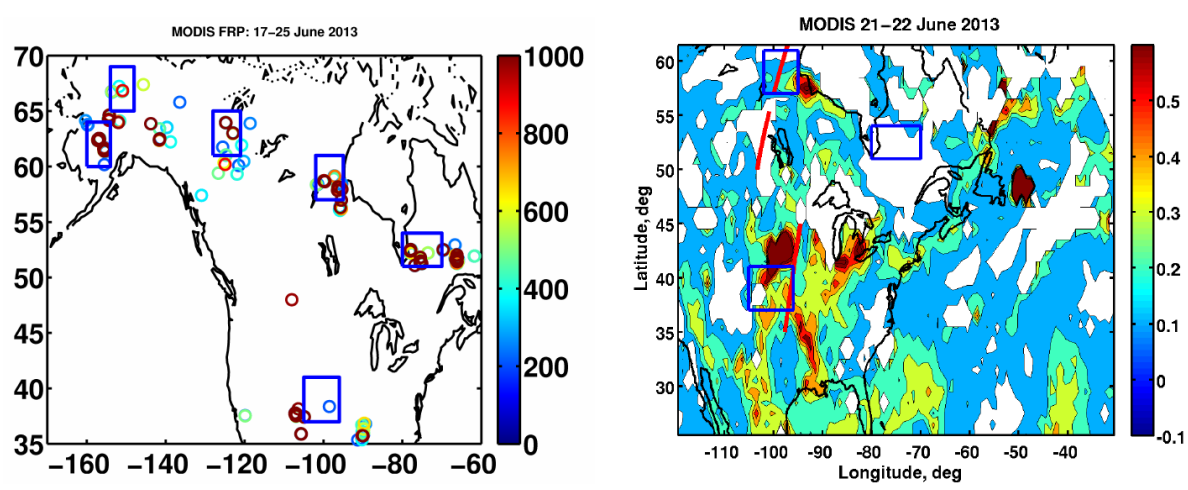

Figure 2. Left: MODIS fire radiative power from 17 to 25 June 2013. Areas with red dots are considered as significant fires. The blue boxes correspond to area chosen for the release of particles in the FLEXPART forward simulation. Right: daily AOD $0.5 \mu \mathrm{m}$ measured by MODIS on 22 June 2013. The CALIOP tracks used to estimate the height of layer influenced by the fires are shown in red on 22 June near Hudson Bay fires and 21 June 2013 near Colorado fires.

aged over $80 \mathrm{~km}$ to compute the plume transmittance whenever it is possible. The attenuated backscatter is then corrected for the molecular and aerosol attenuation using a forward Fernald inversion (Fernald, 1984) before calculating the backscatter ratio $R(z)=\left(\beta_{a}+\beta_{\mathrm{R}}\right) / \beta_{\mathrm{R}}$ at 532 and $1064 \mathrm{~nm}$ using the CALIOP atmospheric density model to calculate the $\beta_{\mathrm{R}}$ Rayleigh backscatter vertical profiles. The aerosol depolarization ratio $\delta_{532}$ is also calculated using the perpendicular to the parallel plus perpendicular polarized aerosol backscatter coefficient. The calibration of the relative ratio between the two $532 \mathrm{~nm}$ channels is based on regular use of a pseudo-depolarizer located ahead of the beam splitter which separates the signal polarized parallel and perpendicular to the plane of the outgoing beam (Winker et al., 2009). We have also derived the color ratio defined as the ratio of the aerosol backscatter coefficients at 1064 and $532 \mathrm{~nm}$ $\left(C_{a}(z)=\beta_{a 1064} / \beta_{a 532}=\left(R_{1064}(z)-1\right) /\left[16\left(R_{532}(z)-1\right)\right]\right)$. The aerosol color ratio can be also written as $C_{a}(z)=2^{-k}$, where $k$ is an exponent depending on the aerosol microphysical properties (Cattrall et al., 2005). The exponent $k$ varies from 0 to 2 when increasing the fine-mode aerosol contribution. These two ratios are provided only for $R(z)>1.3$ because the uncertainty on the depolarization and color ratios are large for weak aerosol layers. Whenever it is possible, the use of nighttime overpasses is preferred to improve the signal-to-noise ratio (SNR).

The transport of the aerosol sources is analyzed using the FLEXPART model version 8.23 (Stohl et al., 2002) driven by 6-hourly ECMWF analysis (T213L91) interleaved with operational forecasts every $3 \mathrm{~h}$. The model is run using a forward simulation with a tracer released within a volume estimated from the satellite observations. The release time period ranges from 1 to 3 days according to the MODIS AOD observations. The total mass of the tracer emitted is estimated using the aerosol concentration given in the NAAPS Global Aerosol Model simulations and FLEXPART calculates the gridded tracer concentration in $\mathrm{ng} \mathrm{m}^{-3}$. Consider- ing the uncertainty in the estimate of the emitted tracer mass, the tracer distribution in the ChArMEx domain is analyzed using a relative mass fraction between the emitted mass and the calculated mass within the model grid cell. A factor is applied to calculate this ratio in order to take into account on the one hand the difference between the emission volume $\left(\approx 5 \times 10^{5} \mathrm{~km}^{3}\right)$ and the grid cell volume of the tracer concentration field $\left(\approx 2 \times 10^{3} \mathrm{~km}^{3}\right)$ and, on the other hand, the time difference between the emission period (1-3 days) and the integration time $(6 \mathrm{~h})$ used for the calculation of the tracer gridded concentration. The relative mass fraction is $100 \%$ when the air mass is advected above the $0.5^{\circ} \times 0.5^{\circ}$ grid cell chosen for the gridded concentration calculation, without dilution $(<100 \%)$ or concentration $(>100 \%)$ of the tracer.

\subsection{North American biomass burning aerosol}

The MODIS FRP distributions are plotted in Fig. 2 from 17 to 25 June 2013 showing the six main fire regions over Canada and Colorado. The map of the $0.5 \mu \mathrm{m}$ daily AOD MODIS also show aerosol plumes on 22 June near Hudson Bay, Colorado, and over the Atlantic Ocean where the AOD is $>0.4$. The white area on the daily mean MODIS map often corresponds to the cloud distribution, which was high over Québec explaining the lack of large AOD daily mean values near this strong BB source. Nearby CALIOP tracks on 21 June over Colorado and 22 June over Canada show the vertical extent of the aerosol layers related to the fires (Fig. 3). The aerosol layers reach $8 \mathrm{~km}$ over Colorado, while they remain below $4 \mathrm{~km}$ over Canada. The aerosol depolarization ratio is less than $7 \pm 3 \%$ for the layers over Canada, while it is near $9 \pm 3 \%$ in the mid-troposphere over Colorado. The uncertainties on the CALIOP aerosol depolarization ratio averaged over the two layers are calculated using the error on the $532 \mathrm{~nm}$ backscatter signals. Notice also the high depolarization ratio (>15\%) over Colorado below $3 \mathrm{~km}$ showing that the BB plume overlays dust layers in the lower 

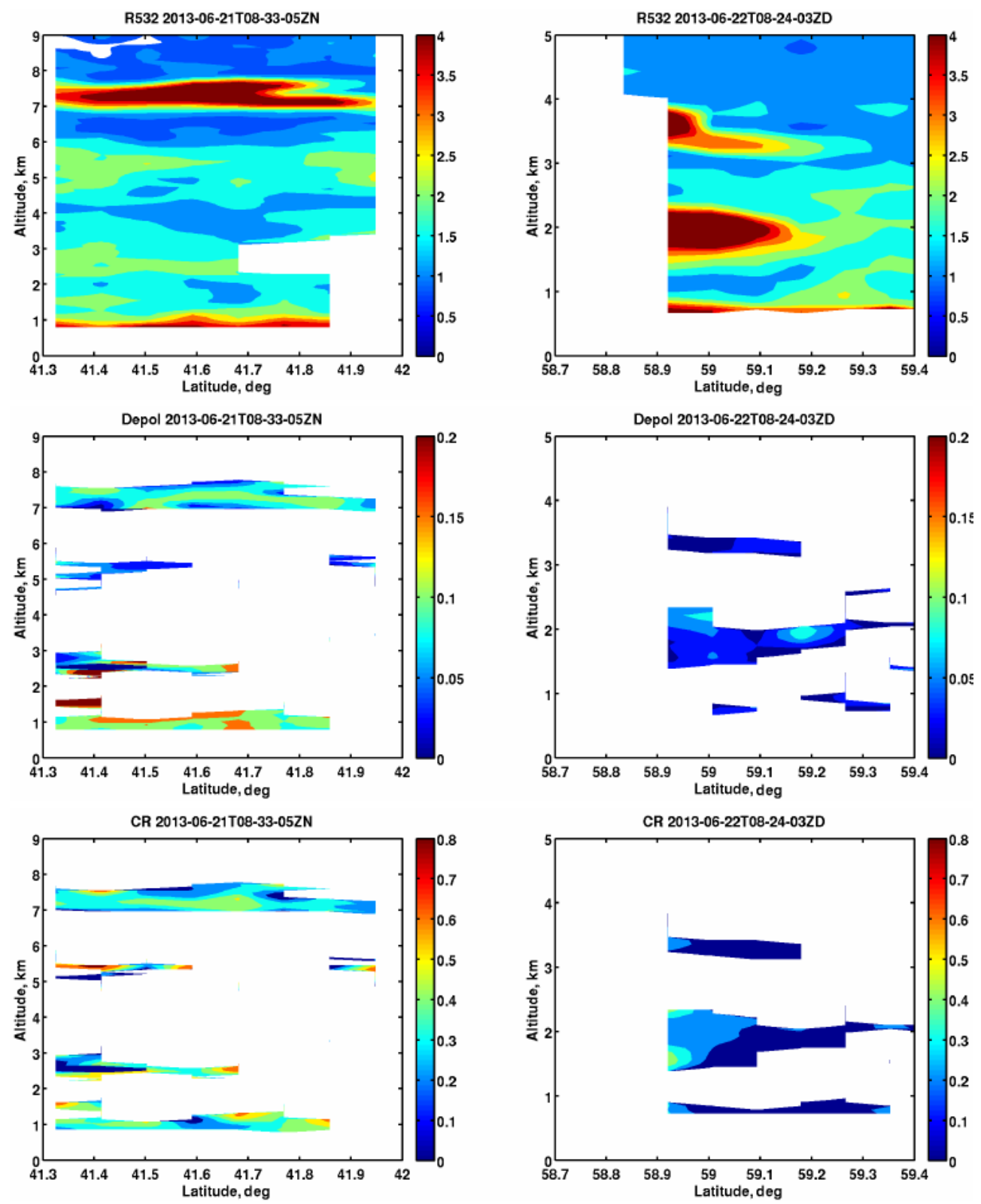

Figure 3. CALIOP vertical cross section of backscatter ratio (top), aerosol depolarization ratio (middle), and aerosol color ratio (bottom) for the two tracks shown in Fig. 2 on 21 (left) and 22 (right) June 2013. Depolarization and color ratios are only reported for backscatter ratio $>$ 2. Aerosol layers on 21 and 22 June 2013 are near the Colorado and Canadian fires, respectively.

troposphere. The six areas shown in blue in Fig. 2 are considered for a forward run of FLEXPART in order to study the long-range transport of the Canadian and Colorado biomass burning tracer. The depth of the volume is set according to the CALIOP vertical distributions shown in Fig. 3. The parameters of the different BB sources considered in the FLEXPART simulations are given in Table 1.

The map of the biomass burning tracer plume over the ChArMEx domain on 27 and 28 June is shown in Fig. 4 using the relative fraction between the emitted mass and the simulated mass in the grid cell of the tracer field as explained be- fore. Two different maps are given for the Canadian and Colorado fire contributions respectively. The Canadian plume crossed the whole western Mediterranean basin, being over Minorca already on 27 June at 06:00 UT and passing over Sicily on 28 June during the day. The Colorado fires do not play a major role in the aerosol layers observed on 27 June, but according to the transport model they could be observed on 28 June mainly over Spain and also in a $200 \mathrm{~km}$ wide strip parallel to a line from Gibraltar to Messina. The vertical cross sections (Fig. 5) show that the front edge of the Canadian fires is above $4 \mathrm{~km}$ on 27 June while the tails brought 

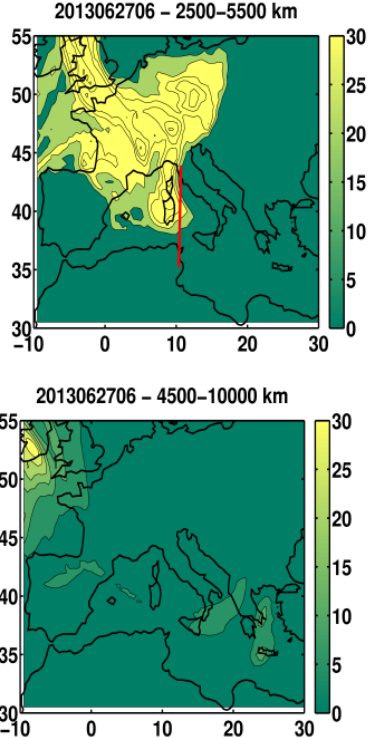

Figure 4. Map of the relative fraction of the FLEXPART biomass burning tracer plume in \% for the Canadian (top) and Colorado (bottom) fires on 27 June 2013 at 06:00 UT (left) and 28 June at 18:00 UT (right). The altitude range corresponds to the vertical levels included in the calculation of the tracer relative fraction.

aerosol at lower altitudes in the $1-4 \mathrm{~km}$ range on 28 June. The Colorado fires can be only detected above $5 \mathrm{~km}$. The relative mass fraction is larger than $30 \%$ in the Canadian fire plume showing that a significant part is indeed advected above the Mediterranean while the remaining part is transported to central Europe as observed by the EARLINET lidar network in Germany (Gross et al., 2015). The relative fraction of the Colorado fires remains in the range 20-30\% because the major part of the plume remains over Spain and the Atlantic Ocean.

\subsection{North American dust layers}

Modeling and satellite observations suggest that the western USA is a significant contributor to the global mineral dust aerosol budget (Ginoux et al., 2001), and mineral dust emissions from this source region may have increased during the last 20 years (Brahney et al., 2013). Several dust blows hit Utah, Colorado and Wyoming in June 2013 due to the very dry conditions and strong winds, which were also the cause of the Colorado forest fires (Hahnenberger and Nicoll, 2012). The NAAPS aerosol transport model simulations indicate elevated surface dust concentrations $\left(>300 \mu \mathrm{g} \mathrm{m}^{-3}\right)$ from 19 to 22 June 2013 in a region almost similar to the large MODIS AOD area related to the Colorado fires. It also explains the aerosol layers with large depolarization seen by CALIOP on 21 June 2013 at $41^{\circ} \mathrm{N}$ at $3 \mathrm{~km}$ below the Colorado fires (Fig. 3). In addition to the local sources coming from western USA, the MODIS maps on 20 and 21 June also show that dust streamers are transported at latitudes north of $30^{\circ} \mathrm{N}$ from the large-scale Saharan dust plume, crossing the Atlantic because of the trade winds. Three streamers are shown in Fig. 6 over the Atlantic Ocean, where the $0.5 \mu \mathrm{m}$ AOD is enhanced with values $>0.3$. Nearby CALIOP tracks on 20 and 21 June show that the AOD enhancement is indeed related to the contribution of aerosol layers with large depolarization $>20 \%$ (Fig. 7). The uncertainty on the average depolarization ratio for the dust layers is of the order of $5 \%$. The three areas shown in blue in Fig. 6 are considered in our study in order to analyze the role of dust layers over the Atlantic in the aerosol distribution over the Mediterranean Sea. According to the CALIOP vertical cross sections, the northern layer at $42^{\circ} \mathrm{N}$ was already uplifted in the altitude range $3-5 \mathrm{~km}$ while the dust plumes near $30^{\circ} \mathrm{N}$ remain below $3 \mathrm{~km}$. Four areas are then selected for a FLEXPART forward run of dust tracers (see Table 2). The emission volume is set according to the MODIS AOD anomaly horizontal extents and the CALIOP vertical distribution of the dust layers. The emission period is chosen between 20 and 22 June for the dust layers over the Atlantic when the AOD anomalies are observed with MODIS, while the time frame for the High Plains region dust source is set according to the NAAPS model simulations.

The amount of tracer related to the High Plains dust sources was found to be negligible over the ChArMEx area during the period 27 and 28 June (mass fraction $<10 \%$ ), and it will not be considered any further. It may have been however mixed with the lower boundary of the Colorado fire plume seen at higher altitudes as shown in the previous section. The maps of the Atlantic dust tracer plume over the ChArMEx campaign domain are shown on 27 and 28 June in Fig. 8. The values of the mass fraction are significant ( $>30 \%$ ), showing that the contribution of long-range transport of dust cannot be neglected even during the event of biomass burning aerosol transport to Europe. A first plume of dust was advected across the western Mediterranean basin already before 27 June, and a second crossed the basin on 28 June. The tail of the first one is at relatively low altitude $(<4 \mathrm{~km})$ on 27 June while the second one is above $5 \mathrm{~km}$ on 28 June.

\subsection{Saharan dust}

Although the synoptic wind conditions (northwesterly flow) from 25 to 29 June 2013 were not favorable for the export of Saharan dust to the basin as explained in Mallet et al. (2016), it is important to set the northern limit of the area influenced by the northward transport of Saharan dust. The characteristics of the dust emissions were estimated using the Multi-angle Imaging SpectroRadiometer (MISR) AOD maps for the period 22 to 28 June (not shown) because the multiangle observations are better suited to distinguish surface and dust contribution to the solar reflection. The depth of the Saharan dust layer has been estimated looking at several CALIOP overpasses above northern Africa during the same period. A FLEXPART forward run with a Saharan dust 

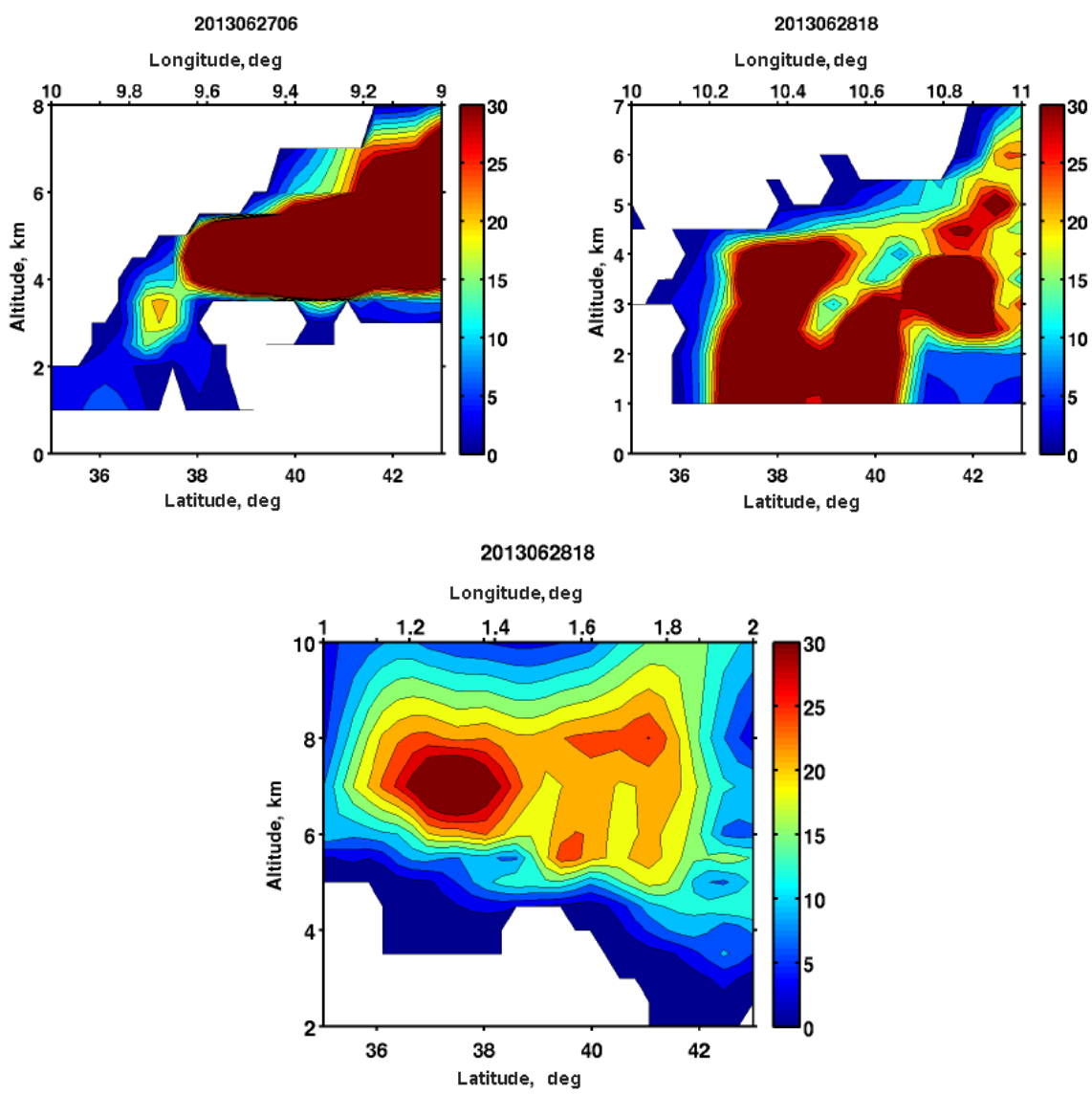

Figure 5. Vertical cross section of the relative fraction of the FLEXPART biomass burning tracer in $\%$ for the Canadian fires on 27 June 2013 at 06:00 UT (top left), 28 June at 18:00 UT (top right), and the Colorado fires on 28 June at 18:00 UT (bottom).

tracer was made for a wide area over northern Africa in the box $\left(24-34.5^{\circ} \mathrm{N}, 0-10^{\circ} \mathrm{E} ; 0-6 \mathrm{~km}\right)$ from 23 to 28 June 2013.

The vertical layering of the Saharan dust tracer over the ChArMEx domain is shown on 28 June in Fig. 9. As expected for a nearby source, the relative mass fraction is very large $(>100 \%)$. Although the dust outflow from Sahara is transported above Lampedusa, it remains south of $36.6^{\circ} \mathrm{N}$ between Lampedusa and Cagliari. No Saharan dust is expected above Minorca. The altitude of the dust plume is between 2.5 and $4.5 \mathrm{~km}$ because the uplifting in the westerly flow is very limited.

\section{Aerosol observations in the Mediterranean basin}

In this section, the ChArMEx aircraft or ground-based lidar observations and the CALIOP vertical cross sections on 27 and 28 June 2013 are compared with the expected contributions of the different aerosol sources transported across the Atlantic.

\subsection{Spatial distribution of the aerosol layers}

Three nighttime CALIOP overpasses are suitable for a comparison with the different BB plumes: 27 June at $10^{\circ} \mathrm{W}$ and at $10^{\circ} \mathrm{E}$, and 28 June at $0^{\circ} \mathrm{W}$. The backscatter ratio $R(z)$ and the aerosol depolarization ratio $\delta_{532}$ are shown in Fig. 10 in the latitude range where cloud-free sky made possible the observations of aerosol layers. The $R(z)$ values are larger than 3 in these layers. On 27 June, the layers are in the altitude range 5 to $7.5 \mathrm{~km}$ at $10^{\circ} \mathrm{E}$ while it is between 2 and $5 \mathrm{~km}$ at $10^{\circ} \mathrm{W}$. In both cases low $\delta_{532}$ values $(<10 \%)$ are found, showing that the plumes are not mixed with a significant amount of dust (except at $10^{\circ} \mathrm{W}$ where $\delta_{532}$ may reach $10 \%$ in some layers). The uncertainty for $\delta_{532}$ is of the order of $3 \%$. These results are in good agreement with the characteristics of the Canadian fire plumes discussed in Sect. 3 . Indeed it was found that the front edge of the plume was at $10^{\circ} \mathrm{E}$ on 27 June with an altitude range $4-7 \mathrm{~km}$, while the tail is at $10^{\circ} \mathrm{W}$ in the altitude range $2-5 \mathrm{~km}$ (see vertical cross section on 28 June in Fig. 5). Although the Colorado fires may be present in the 27 June CALIOP cross section at $10^{\circ} \mathrm{W}$ according to the FLEXPART simulations, the altitude range of the observed aerosol layers is not consistent with 


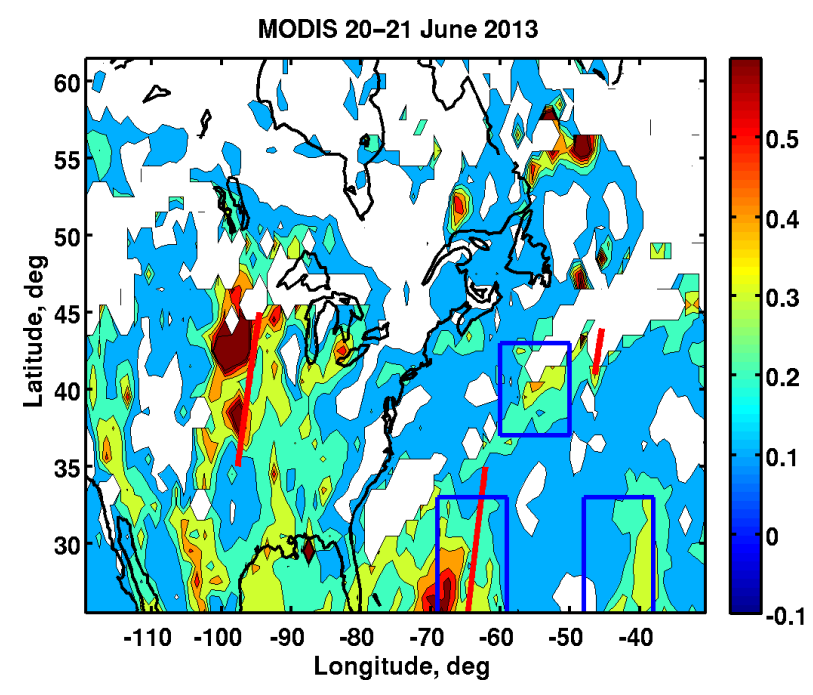

Figure 6. Daily AOD $0.5 \mu \mathrm{m}$ measured by MODIS on 20 June 2013. The CALIOP tracks used to estimate the heights of the dust layers over the Atlantic Ocean are shown in red on 20 June at $42^{\circ} \mathrm{N}$ and 21 June at $30^{\circ} \mathrm{N}$. The blue boxes correspond to areas chosen for the release of particles in the FLEXPART forward simulation.

the influence of the Colorado BB plume, which is expected at an altitude above $5 \mathrm{~km}$. On 28 June at $0^{\circ} \mathrm{W}$, the CALIOP observations show also aerosol layers in the $3-5 \mathrm{~km}$ altitude range, with slightly higher depolarization ratio $(\approx 10 \pm 3 \%)$, but still in the range expected for biomass burning aerosol (Nisantzi et al., 2014). The altitude range is again in good agreement with a major role of the tail of the Canadian fire plume.

Several ground-based lidar observations have also identified aerosol plumes possibly related to the transatlantic transport. The characteristics of the aerosol layers are summarized in Table 3. The Minorca lidar data are discussed in a companion paper by Chazette et al. (2016). An aerosol layer between 3 and $5 \mathrm{~km}$ seen in Minorca is quite similar to the CALIOP observations on 28 June. A second layer between 5 and $7 \mathrm{~km}$ is also seen in Minorca with a noticeable depolarization $\left(\delta_{355}>12 \pm 1 \%\right)$. The upper layer is not seen by CALIOP because it is expected at latitudes higher than $40^{\circ} \mathrm{N}$ and is masked by overlaying clouds. In Minorca the vertical profiles of the water vapor mixing ratio were also measured during the night (Chazette et al., 2014) showing elevated mixing ratio $>1 \mathrm{~g} \mathrm{~kg}^{-1}$ above $5 \mathrm{~km}$ and values near $0.5 \mathrm{~g} \mathrm{~kg}^{-1}$ in the aerosol layer observed around $4 \mathrm{~km}$. The time series of the Minorca lidar is also useful to estimate the horizontal range of $\mathrm{BB}$ plume. The plume is observed for $24 \mathrm{~h}$ from 27 June at 00:00 UT to 28 June at 12:00 UT, and the wind speed at $4 \mathrm{~km}$ is between 30 and $40 \mathrm{~km} \mathrm{~h}^{-1}$. Therefore, the plume zonal extent is of the order of $1200 \mathrm{~km}$. It is very similar to the size of the Canadian tracer plume obtained in the FLEXPART simulations $\left(15^{\circ}\right.$ longitude difference between the front edge and the tail).
As expected the Barcelona lidar detects similar features: a strong layer between 5 and $7 \mathrm{~km}$ with $\delta_{532} \approx 10 \%$ and an optically thin layer between 3 and $5 \mathrm{~km}$ with $\delta_{532}<10 \%$. The spectral variation of the aerosol depolarization ratio between Barcelona and Minorca cannot be accurately estimated but is less than 1.5. It is consistent with a small influence of urban aerosol (Burton et al., 2012). When looking at the Lampedusa lidar data at $35^{\circ} \mathrm{N}$, a layer is seen between 2 and $4 \mathrm{~km}$ on 28 June, which is influenced by the Saharan dust outflow discussed in Sect. 3 since $\delta_{532} \geq 30 \%$, i.e., a value similar to other dust layers observed over Minorca during ChArMEx (Chazette et al., 2016).

The Lampedusa lidar measures aerosol layers in the 2 $4 \mathrm{~km}$ altitude range on both days, but with very different optical characteristics. A dust layer with $\delta_{532}>30 \%$ on 28 June at 12:00 UT while a mixture of dust and BB aerosol is seen on 27 June from 08:00 to 16:00 UT. The aerosol layer seen by CALIOP on 27 June at 01:00 UT near $36^{\circ} \mathrm{N}$ has optical characteristics close to the layer observed in Lampedusa on 27 June (Fig. 10), i.e., a depolarization between 10 and $15 \%$ and LR between 50 and $55 \mathrm{sr}$.

The LNG airborne lidar data obtained during ChArMEx will be thoroughly discussed in a forthcoming paper by Pelon et al. (2016). Here we will only consider the vertical structure of the aerosol layers observed on 28 June 2013 along the loop shown in Fig. 1. The three corresponding vertical cross sections of attenuated $R(z)$ at $532 \mathrm{~nm}$ are shown in Fig. 11 . Three interesting regions can be identified:

A. the $38.2^{\circ} \mathrm{N}$ layer at $2-4 \mathrm{~km}$ on the Cagliari-Lampedusa section and at $11-14^{\circ} \mathrm{E}$ on the return section between Messina and Cagliari;

B. the upper altitude layer in the 4-6 km altitude range covering a southwest $\left(36^{\circ} \mathrm{N}, 12^{\circ} \mathrm{E}\right)$ to northeast $\left(39^{\circ} \mathrm{N}\right.$, $\left.15^{\circ} \mathrm{E}\right)$ band, the width of which is of the order of $100 \mathrm{~km}$;

C. a low-altitude layer between 2 and $4 \mathrm{~km}$ south of $36^{\circ} \mathrm{N}$, which corresponds to the layer seen by the Lampedusa lidar.

The spatial distribution of the aerosol layers seen by the LNG lidar corresponds quite well to the position of North American BB plumes and the expected latitudinal extent of the Saharan dust calculated with the FLEXPART simulation in Sect. 3. Indeed layer A is related to the tail of the Canadian BB plume. Layer B is also in the latitude range of the Canadian BB plume, possibly mixed with the Colorado BB plume present between Gibraltar and Messina (see Fig. 4). Layers A and B seen by the LNG airborne lidar on 28 June are also consistent with the superposition of two different aerosol layers seen above Minorca $24 \mathrm{~h}$ before. In layer B, $\delta_{355} \approx 10 \pm 1 \%$, i.e., higher than the low values found in layer $\mathrm{A}\left(\delta_{355} \leq 5 \pm 2 \%\right)$. 

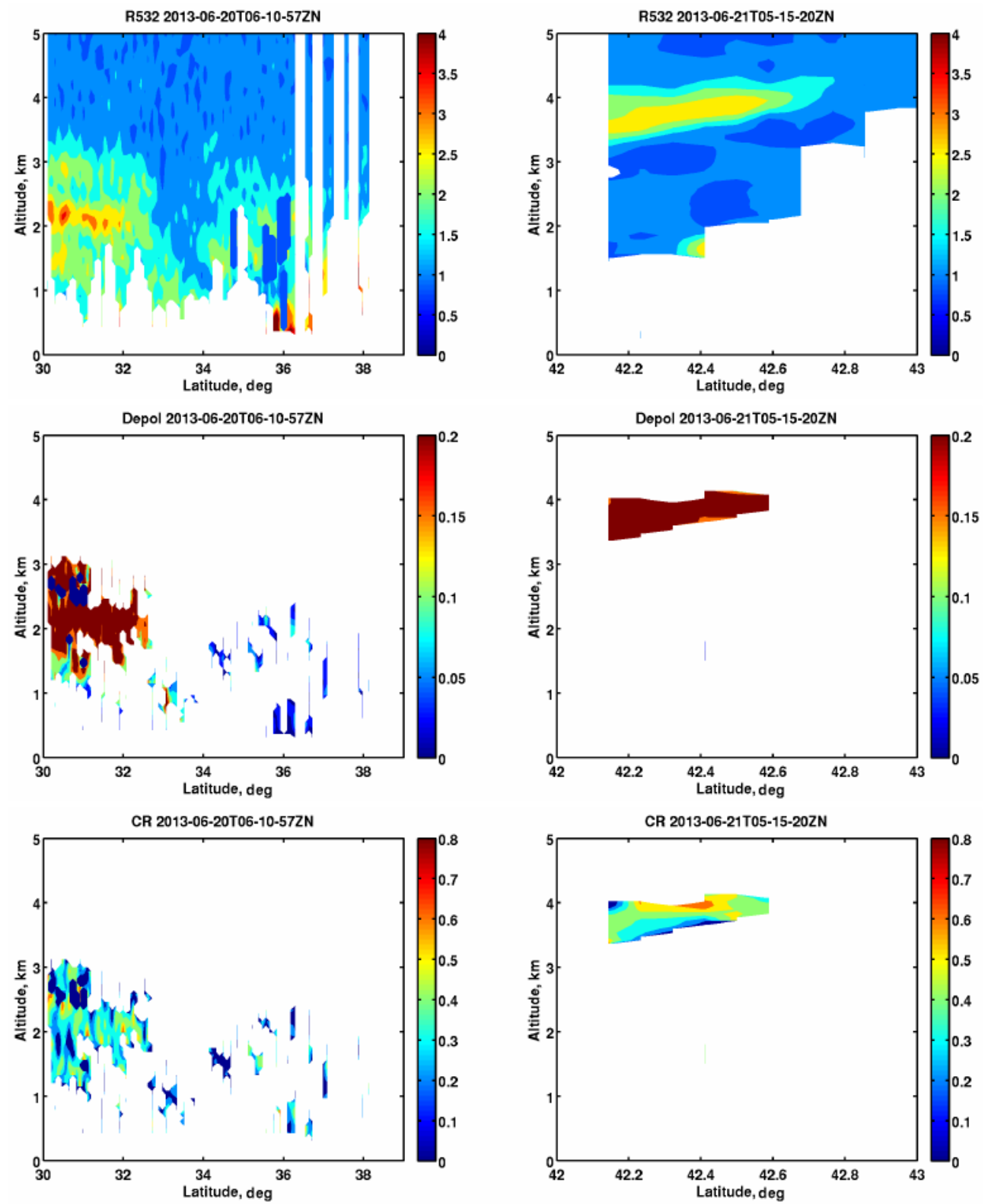

Figure 7. Same as Fig. 3 for the two tracks shown in Fig. 6 on 20 (left) and 21 (right) June 2013. Dust layers are seen above the Atlantic Ocean in the altitude range $1-4 \mathrm{~km}$, near 32 and $42^{\circ} \mathrm{N}$, on 20 and 21 June 2013 , respectively.

Table 1. Characteristics of the biomass burning tracer emission used for the forward FLEXPART simulation. The emitted mass is only a rough estimate explaining the use of relative mass fraction in the simulation analysis. Altitude is given above ground level.

\begin{tabular}{llrrr}
\hline Aerosol source & Release time & Horizontal domain & $\begin{array}{r}\text { Vertical } \\
\text { range, km }\end{array}$ & $\begin{array}{r}\text { Emitted } \\
\text { mass, kg }\end{array}$ \\
\hline Québec BB & 18-24 June 2013 & $80 / 70^{\circ} \mathrm{W}, 51 / 54^{\circ} \mathrm{N}$ & $0-3$ & $3 \times 10^{7}$ \\
Manitoba BB & 20-24 June 2013 & $102 / 95^{\circ} \mathrm{W}, 57 / 61^{\circ} \mathrm{N}$ & $0-3$ & $2.5 \times 10^{7}$ \\
NWT BB & 22-24 June 2013 $^{\circ}$ & $128 / 121^{\circ} \mathrm{W}, 61 / 65^{\circ} \mathrm{N}$ & $0-5$ & $2 \times 10^{7}$ \\
N. Alaska BB & 17-19 June 2013 $^{\circ} 160 / 154^{\circ} \mathrm{W}, 60 / 64^{\circ} \mathrm{N}$ & $0-5$ & $1.9 \times 10^{7}$ \\
S. Alaska BB & 19-22 June 2013 $^{\circ} 154 / 148^{\circ} \mathrm{W}, 65 / 69^{\circ} \mathrm{N}$ & $0-5$ & $3.6 \times 10^{7}$ \\
Colorado BB & 19-22 June 2013 $^{\circ} 105 / 96^{\circ} \mathrm{W}, 37 / 41^{\circ} \mathrm{N}$ & $0-6$ & $5 \times 10^{7}$ \\
\hline
\end{tabular}


Table 2. Same as Table 1 for the dust tracer emission.

\begin{tabular}{lcrrr}
\hline Aerosol source & Release time & Horizontal domain & $\begin{array}{r}\text { Vertical } \\
\text { range, km }\end{array}$ & $\begin{array}{r}\text { Emitted } \\
\text { mass, kg }\end{array}$ \\
\hline Dust High Plains & 19-22 June 2013 & $105 / 99^{\circ} \mathrm{W}, 37 / 40^{\circ} \mathrm{N}$ & $0-3$ & $5 \times 10^{7}$ \\
Dust over Atlantic & 20-21 June 2013 & $60 / 50^{\circ} \mathrm{W}, 37 / 43^{\circ} \mathrm{N}$ & $1-5$ & $5 \times 10^{7}$ \\
Dust over Atlantic & 20-21 June 2013 & $69 / 59^{\circ} \mathrm{W}, 25 / 33^{\circ} \mathrm{N}$ & $1-4$ & $5 \times 10^{7}$ \\
Dust over Atlantic & 20-21 June 2013 & $48 / 38^{\circ} \mathrm{W}, 25 / 33^{\circ} \mathrm{N}$ & $1-4$ & $5 \times 10^{7}$ \\
\hline
\end{tabular}
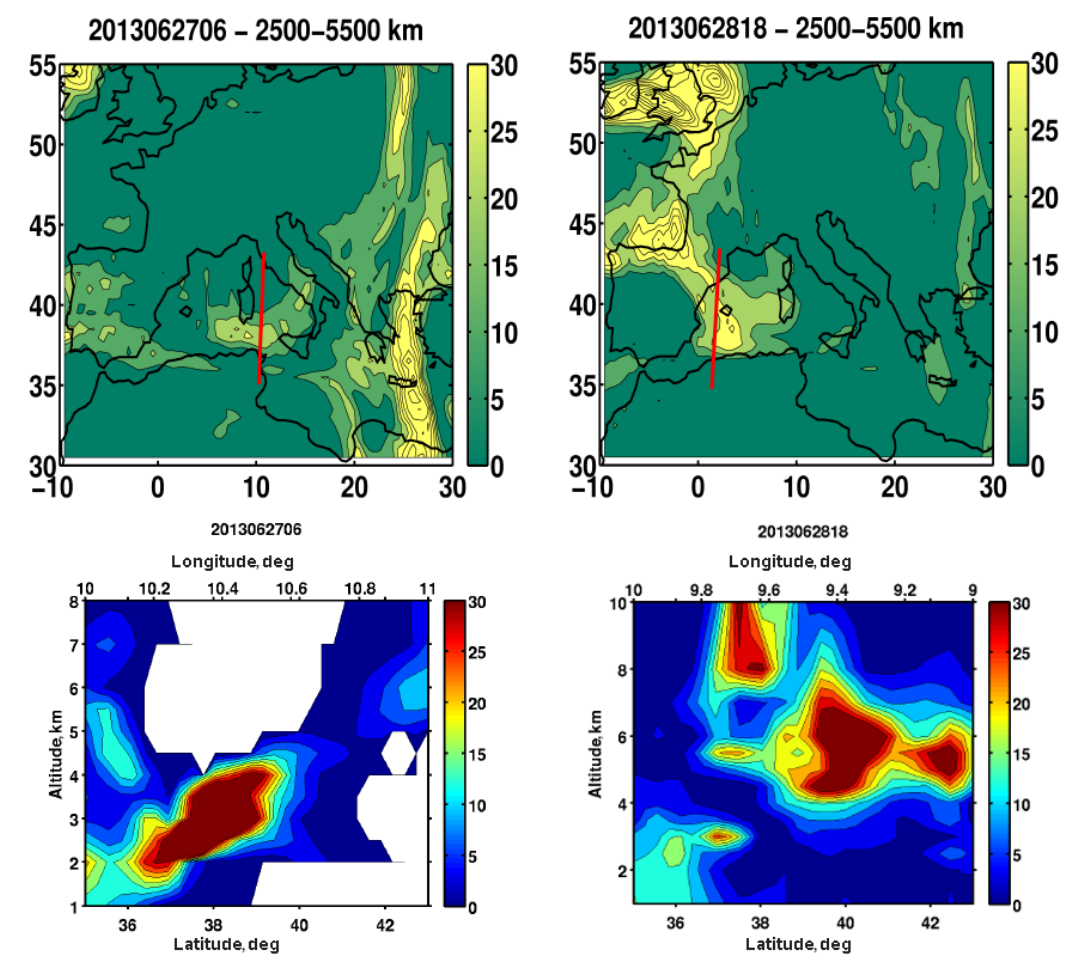

Figure 8. Map (top) and vertical cross section (bottom) of the relative fraction of the FLEXPART Atlantic dust tracer in \% on 27 June 2013 at 06:00 UT (left) and 28 June at 18:00 UT (right). The altitude ranges in the top figures correspond to the vertical levels included in the calculation of the tracer relative fraction.

\subsection{Aerosol source attribution}

Although the comparison with the position of the FLEXPART tracer plumes can already help to attribute a specific source to the observed layers in the ChArMEx area, it can be further checked by calculating the potential emission sensitivity (PES) values by running the FLEXPART model in the backward mode for 10-11 days to identify the area where surface emissions may influence the observed aerosol structure seen by CALIOP, the Minorca ground-based lidar and the LNG airborne instrument. The PES is given in seconds in order to be multiplied by model surface fluxes to produce concentrations at the receptor location. The PES is calculated using $6 \mathrm{~h}$ averages on a three-dimensional $1^{\circ} \times 1^{\circ} \times 1 \mathrm{~km}$ grid. The results are shown for the CALIOP and Minorca observations on 27 June 2013 (Fig. 12). Similar calculations were also made for layers $\mathrm{A}, \mathrm{B}$ and $\mathrm{C}$ seen by the airborne lidar on 28 June (Fig. 13). The simulations for the layers seen by CALIOP on 28 June at 02:00 UT are not shown because they are very similar to the results obtain for the Minorca lidar on 27 June at 12:00 UT or for layer B seen by LNG.

The aerosol layers observed by CALIOP along the two cross sections at $10^{\circ} \mathrm{W}$ and $10^{\circ} \mathrm{E}$ are indeed mainly related to aerosol sources over Canada and Alaska, but the retroplume altitude and latitude at $60^{\circ} \mathrm{W}$ are quite different when reaching the Atlantic Ocean. The probability of dust and biomass mixing is higher for the CALIOP layers at $10^{\circ} \mathrm{W}$, which is located in the $40-50^{\circ} \mathrm{N}$ latitude band at lower altitude $(5-7 \mathrm{~km})$ than for the CALIOP layers at $10^{\circ} \mathrm{E}$. This may explain the slight depolarization difference for the two CALIOP tracks since there are more layers with $\delta_{532} \approx 10 \%$ at $10^{\circ} \mathrm{W}$ than at $10^{\circ} \mathrm{E}$. The mixing of dust layers over the Atlantic and Canadian BB aerosol is even more explicit for the Minorca layer at $6 \mathrm{~km}$ since two branches of elevated PES 

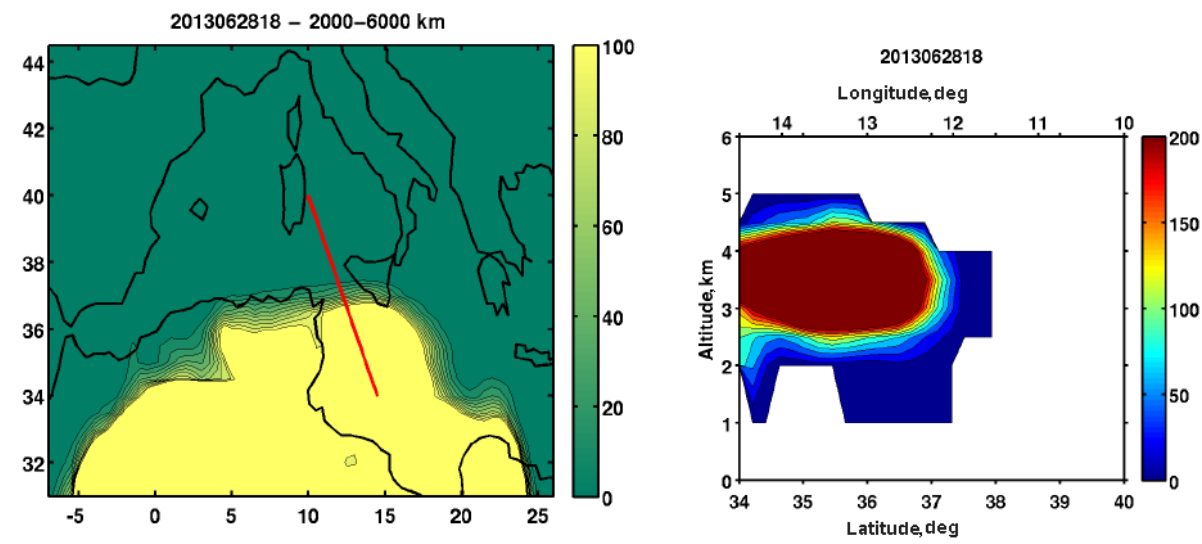

Figure 9. Same as Fig. 8 for the FLEXPART Saharan tracer on 28 June 2013 at 18:00 UT.

Table 3. Characteristics of the aerosol layers observed in the free troposphere by the ground-based lidars listed in Fig. 1 on 27 and 28 June 2013.

\begin{tabular}{|c|c|c|c|c|c|c|}
\hline Lidar & $\begin{array}{r}\text { Wavelength } \\
(\mathrm{nm})\end{array}$ & $\begin{array}{r}\text { Layer } \\
\text { altitude }\end{array}$ & Time period & $\begin{array}{r}\text { Scattering } \\
\text { ratio }\end{array}$ & $\begin{array}{r}\text { Depolarization } \\
\text { ratio }\end{array}$ & $\begin{array}{r}\text { Lidar } \\
\text { ratio }\end{array}$ \\
\hline Minorca & 355 & $5-7 \mathrm{~km}$ & $\begin{array}{l}27 \text { Jun, 00:00 UT to } \\
28 \text { Jun, 00:00 UT }\end{array}$ & $1.87 \pm 0.03$ & $10 \pm 1 \%$ & $42 \pm 5 \mathrm{sr}$ \\
\hline Minorca & 355 & $3-5 \mathrm{~km}$ & $\begin{array}{l}27 \text { Jun, 00:00 UT to } \\
28 \text { Jun, } 12: 00 \text { UT }\end{array}$ & $1.22 \pm 0.02$ & $4 \pm 1 \%$ & $59 \pm 5 \mathrm{sr}$ \\
\hline Barcelona & 532 & $5-7 \mathrm{~km}$ & $\begin{array}{r}26 \text { Jun, 20:00 UT to } \\
27 \text { Jun, 16:00 UT } \\
\text { cloudy after }\end{array}$ & 4.3 & $\approx 10 \pm 2 \%$ & \\
\hline Barcelona & 532 & $3-5 \mathrm{~km}$ & $\begin{array}{r}26 \text { Jun, 12:00 UT to } \\
27 \text { Jun, 16:00 UT } \\
\text { cloudy after }\end{array}$ & 1.4 & $7 \pm 2 \%$ & \\
\hline Lampedusa & 532 & $2-4 \mathrm{~km}$ & $\begin{array}{l}27 \text { Jun, 08:00 UT to } \\
27 \text { Jun, 16:00 UT }\end{array}$ & $1.5 \pm 0.03$ & $12 \pm 2 \%$ & $51 \pm 9 \mathrm{sr}$ \\
\hline Lampedusa & 532 & $2-4 \mathrm{~km}$ & $\begin{array}{l}28 \text { Jun, 08:00 UT to } \\
28 \text { Jun, } 14: 00 \text { UT }\end{array}$ & $2.8 \pm 0.04$ & $30 \pm 2 \%$ & $30 \pm 6 \mathrm{sr}$ \\
\hline
\end{tabular}

are seen over the two aerosol source regions identified for this layer. It explains the relatively higher aerosol depolarization ratio (up to $12 \%$ ) at $6 \mathrm{~km}$ than at $4 \mathrm{~km}$ in Minorca during this episode. Such a transport pathway is also consistent with the water vapor mixing ratio maximum $>1 \mathrm{~g} \mathrm{~kg}^{-1}$ seen by the Minorca water vapor lidar near $6 \mathrm{~km}$ since uplifting of air masses from the lower troposphere above the Atlantic Ocean is likely to increase the humidity in the mid-troposphere.

When considering the PES related to the airborne lidar layers, layer A PES is similar to the $10^{\circ} \mathrm{E}$ plume showing a strong influence of the Canadian aerosol BB source, while layer B PES distribution resembles the results obtained with the Minorca layer seen 1 day earlier. For the dusty layer $\mathrm{C}$ seen both by the aircraft and at the Lampedusa station, the PES distribution shows that there is no transatlantic transport for the period 17 to 28 June while the aerosol sources are mainly located above northern Africa and western Europe at low altitude $(<3 \mathrm{~km})$. Although air masses are still advected from western Europe, Saharan dust emission remains the major aerosol source since western Europe air masses were heavily influenced by Saharan dust layers during the period 16 to 20 June (Mallet et al., 2016). This is consistent with the large depolarization seen above Lampedusa $\left(\delta_{532} \approx 30 \%\right)$.

The ATR42 aircraft also flew between Cagliari and Lampedusa on 28 June around 12:00 UT to sample the aerosol layers with in situ measurements (Pelon et al., 2015). The analysis of the $\mathrm{CO}$ and $\mathrm{BC}$ in situ measurements made on board the ATR42 shows that layers A and B correspond to a $\mathrm{CO}$ excess above the background of the order of $100 \mathrm{ppbv}$ while $\Delta \mathrm{CO}$ is less than $20 \mathrm{ppbv}$ for layer $\mathrm{C}$ (not shown). The $\mathrm{BC}$ variability shows also the same pattern. This is in very good agreement with the conclusions derived from the lidar data analysis coupled with the Lagrangian transport model simulations. 

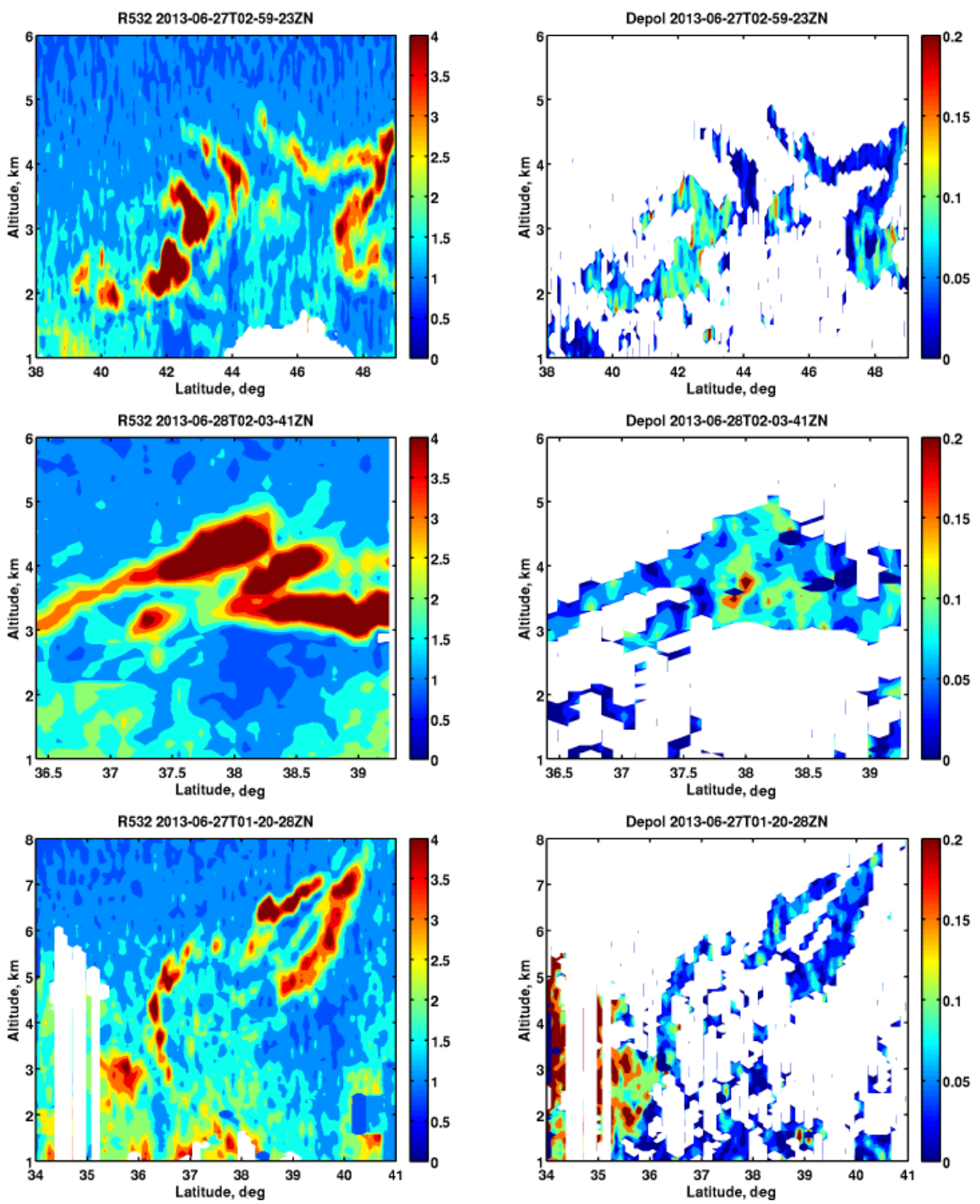

Figure 10. CALIOP vertical cross section of backscatter ratio (left), aerosol depolarization ratio (right) for the three tracks shown in Fig. 1 on 27 June 2013 at 03:00 UT at $10^{\circ} \mathrm{W}$ (top), on 28 June 2013 at 02:00 UT at $0^{\circ} \mathrm{W}$ (middle), and on $27 \mathrm{June} 2013$ at 01:00 UT at 10 $\mathrm{E}$ (bottom).

Table 4. Optical properties of the four types of aerosol encountered during the passage of the BB plume: depolarization ratios $\left(\delta_{532}, \delta_{355}\right)$, lidar ratios $\left(\mathrm{LR}_{532}, \mathrm{LR}_{355}\right)$, and color ratios $\left(\mathrm{CR}_{a} 1064 / 532, \mathrm{CR}_{a} 532 / 355\right)$.

\begin{tabular}{lrrrrrr}
\hline Aerosol type & $\delta_{532}$ & $\delta_{355}$ & $\mathrm{LR}_{532}, \mathrm{sr}$ & $\mathrm{LR}_{355}, \mathrm{sr}$ & $\mathrm{CR}_{a} 1064 / 532$ & $\mathrm{CR}_{a} 532 / 355$ \\
\hline Pure BB (I) & $<5 \%$ & - & $60 \pm 20$ & - & $0.2-0.4$ & - \\
Dusty BB (II) & $5-10 \%$ & $5-8 \%$ & $60 \pm 5^{\mathrm{a}}, 51 \pm 9^{\mathrm{b}}$ & $59 \pm 5$ & $0.4-0.5$ & 0.35 \\
BB-dust mixture (III) & $\approx 10 \pm 2 \%$ & $8-12 \%$ & $45 \pm 5$ & $42 \pm 5$ & - & 0.74 \\
Saharan dust (IV) & $30 \pm 2 \%$ & - & $48 \pm 5^{\mathrm{a}}, 30 \pm 5^{\mathrm{b}}$ & - & - & - \\
\hline
\end{tabular}

${ }^{a}$ Airborne lidar. ${ }^{b}$ Lampedusa lidar. 

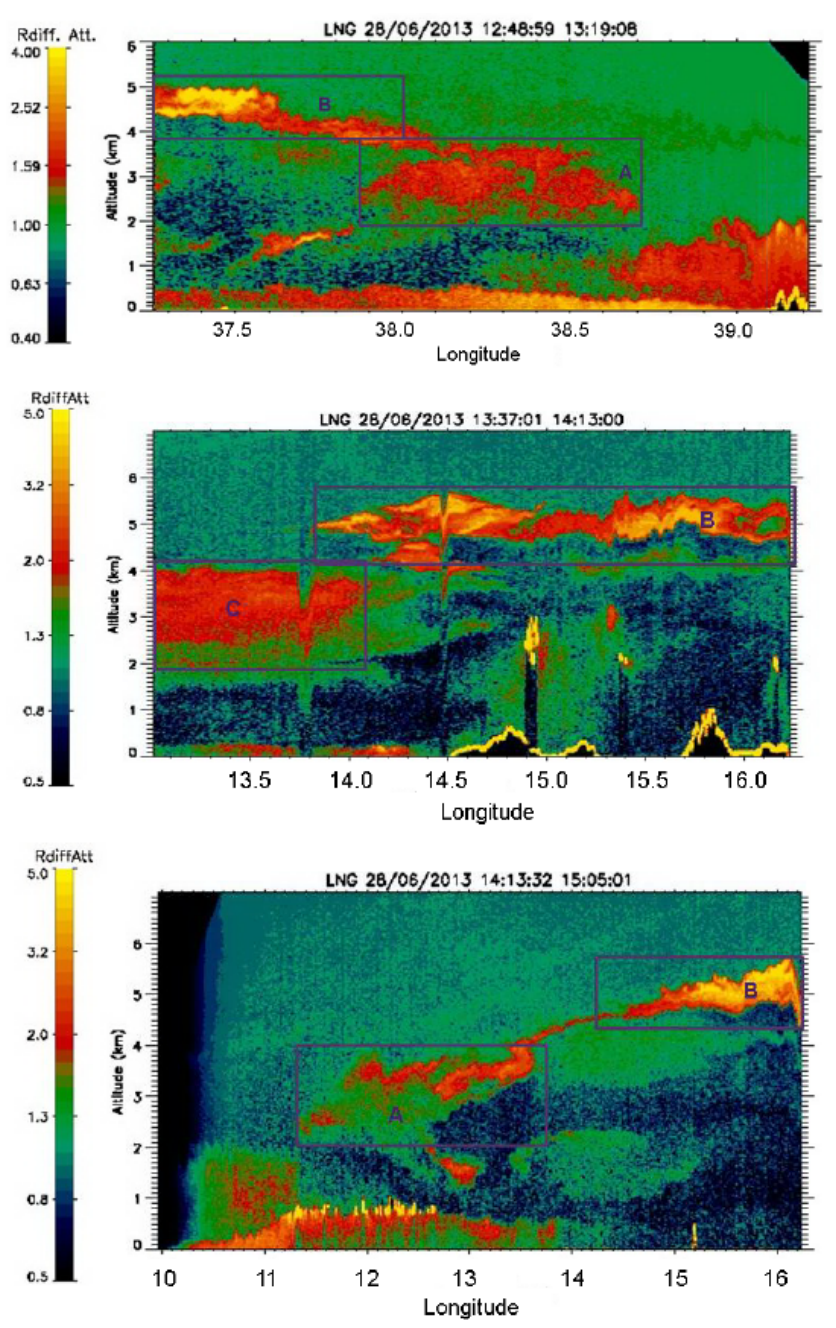

Figure 11. Airborne lidar vertical cross sections of attenuated backscatter ratio at $532 \mathrm{~nm}$ on 28 June 2013 along the loop shown in Fig. 1: (top) Lampedusa-Cagliari around 13:00 UT, (middle) Lampedusa-Messina around 14:00 UT, and (bottom) CagliariMessina around 14:40 UT.

\subsection{Aerosol optical properties}

In this section, we will summarize the results about the aerosol layer optical properties and the aerosol source attribution. The analysis conducted in the previous sections leads to the identification of four different aerosol layers during the passage of the BB plume over the ChArMEx area:

I. pure BB layer at $10^{\circ} \mathrm{E}$ above $4 \mathrm{~km}$ on 27 June 2013 at 01:00 UT (CALIOP);

II. weakly dusty BB layer below $5 \mathrm{~km}$ observed between $10^{\circ} \mathrm{W}$ and $10^{\circ} \mathrm{E}$ on 27 and 28 June at 02:00 UT by CALIOP, the Minorca lidar and layer A seen by LNG flying around Sicily on 28 June;
III. significant mixture of $\mathrm{BB}$ and dust transported across the Atlantic above $5 \mathrm{~km}$ at Minorca on 27 June at 12:00 UT and layer B seen by LNG on 28 June at 14:00 UT;

IV. the outflow of Saharan dust above the sea at latitudes south of $36^{\circ} \mathrm{N}$ on 28 June at 13:00 UT (Lampedusa lidar and layer $\mathrm{C}$ seen by LNG).

For layer I $\delta_{532}$ is $<5 \%$, while the LR at $532 \mathrm{~nm}$ is $60 \pm 20 \mathrm{sr}$ when using the aerosol layer transmission from the averaged L1 CALIOP attenuated backscatter, and it is $65 \mathrm{sr}$ in the level-2 (L2) CALIOP operational aerosol data products. The color ratio is between 0.2 and 0.4. Both LR and $C_{a}$ are in the range expected for a pure BB layer (Burton et al., 2012) in agreement with our source identification.

For layer II $\delta_{532}$ and $\delta_{355}$ are respectively in the range 5-10 and $<8 \%$ with the lowest values on 27 June at $45^{\circ} \mathrm{N}$ along the $10^{\circ} \mathrm{W}$ CALIOP overpass. The LRs calculated from the ground-based and airborne lidars are more accurate, and they are $59 \pm 5 \mathrm{sr}$ at $355 \mathrm{~nm}$ and $60 \pm 5 \mathrm{sr}$ at $532 \mathrm{~nm}$, respectively. The CALIOP 27 June $\left(10^{\circ} \mathrm{W}\right)$ and 28 June LRs at $532 \mathrm{~nm}$ are estimated to be $60 \pm 20 \mathrm{sr}$ and $50 \pm 20 \mathrm{sr}$, respectively, using the L1 data analysis and are of the order of $60 \mathrm{sr}$ for both layers using the L2 operational products. It also gives confidence in the LR retrieval to see the largest LR is obtained where $\delta_{532}$ is minimum. The CALIOP $C_{a}$ is in the range 0.4 0.5 . These aerosol optical parameters are still in the range expected for a BB layer. However differences with the optical parameters found for layer I (higher depolarization and $C_{a}$, slightly lower LR) are consistent with a BB mixed with a small amount of dust or an increase in relative humidity. According to the small values $\left(<0.5 \mathrm{~g} \mathrm{~kg}^{-1}\right)$ of water vapor recorded by the Minorca lidar observations (Chazette et al., 2016), the mixing with a small amount of dust is more likely.

For layer III mainly seen by the Minorca ground-based and airborne lidar, $\delta_{355}$ values are in the range $8-12 \%$, while LRs are $45 \pm 5 \mathrm{sr}$ and $42 \pm 5 \mathrm{sr}$ at 532 and $355 \mathrm{~nm}$, respectively. The LR of layer B seen by LNG is calculated by including also the contribution of the underlying layer between 3 and $4 \mathrm{~km}$ to get a better molecular reference. Following the methodology proposed by Tesche et al. (2009), the aerosol depolarization value for layer III is consistent with a contribution of $20-30 \%$ of dust and $80-70 \%$ of BB aerosol in the total aerosol backscatter in layer III, if we assume that pure dust and pure BB aerosol types have $\delta_{355}$ of 25 and $5 \%$, respectively, and LRs at $355 \mathrm{~nm}$ of $45 \pm 10$ and $60 \pm 10 \mathrm{sr}$, respectively. It is also interesting to calculate $C_{a}$ between 355 and $532 \mathrm{~nm}$ using the Barcelona and Minorca observations assuming that $R(z)$ is stationary during the advection of the aerosol layers between Barcelona and Minorca. The $C_{a}$ value is 0.74 for layer III while it is only 0.35 for layer II. It is consistent with a larger contribution of the accumulation mode when $\mathrm{BB}$ is mixed with dust, but also with a larger water vapor mixing ratio $\left(1 \mathrm{~g} \mathrm{~kg}^{-1}\right)$ for layer III than for layer II. 

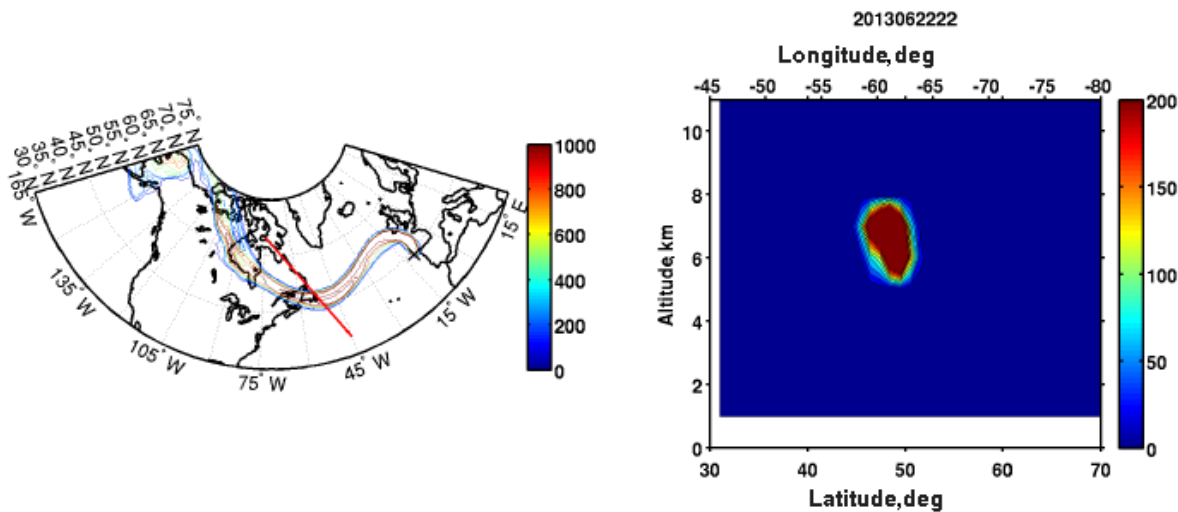

2013062400
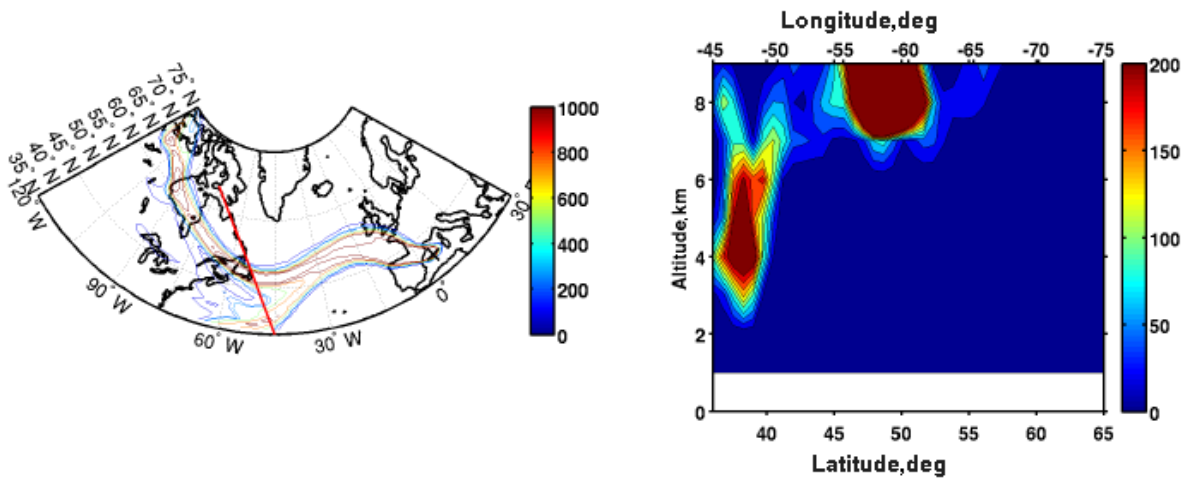

2013062403
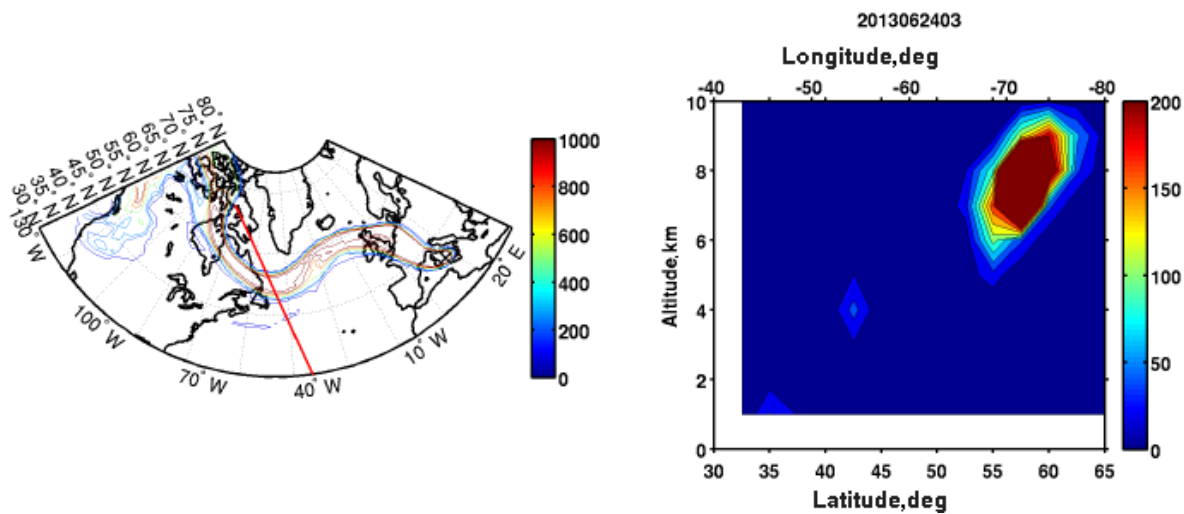

Figure 12. Left: FLEXPART potential emission sensitivity (PES) in seconds for three aerosol layers identified by CALIOP and Minorca lidar: 27 June 2013 at 02:00 UT, $10^{\circ} \mathrm{W}, 43^{\circ} \mathrm{N}$ (top); 27 June at 12:00 UT, in Minorca (middle); and $27 \mathrm{June}$ at 01:00 UT, $10^{\circ} \mathrm{E}, 39^{\circ} \mathrm{N}$ (bottom). The PES vertical cross section are along the red line following the North American east coast (right).

For layer IV larger depolarization up to $30 \%$ is seen by the Lampedusa lidar at $532 \mathrm{~nm}$. The LRs calculated by the LNG lidar and the ground-based lidar at $532 \mathrm{~nm}$ are respectively $48 \pm 5$ and $30 \pm 10 \mathrm{sr}$. The layer optical parameters are consistent with a dust plume with a large depolarization, while a large variability is observed for LR. The large depolarization ratio and the low $\mathrm{LR}$ value at $355 \mathrm{~nm}$ are quite similar to previous observations by Di Iorio et al. (2009) in fresh dust exported over the Mediterranean Sea. The strong variation in the $\mathrm{LR}$ values between layer $\mathrm{C}$ of the $\mathrm{LNG}$ lidar at $13.5^{\circ} \mathrm{E}$ and the Lampedusa observations at $12.5^{\circ} \mathrm{E}$ suggests an in- crease of the mixing between the northward African dust outflow and the BB plume as the aircraft moved across the boundary between layer IV and II between Lampedusa and the southern cape of Sicily.

The aerosol properties and spatial distribution of the four aerosol types are summarized in Table 4 and Fig. 14 respectively. The spatial distribution of the MODIS AOD at $0.5 \mu \mathrm{m}$ is also shown in Fig. 14, where the largest AOD values are seen before the plume dispersion above northern Spain. For the type II aerosol, i.e., an aged BB plume seen below $5 \mathrm{~km}$ and mixed with a small amount of dust mainly from conti- 

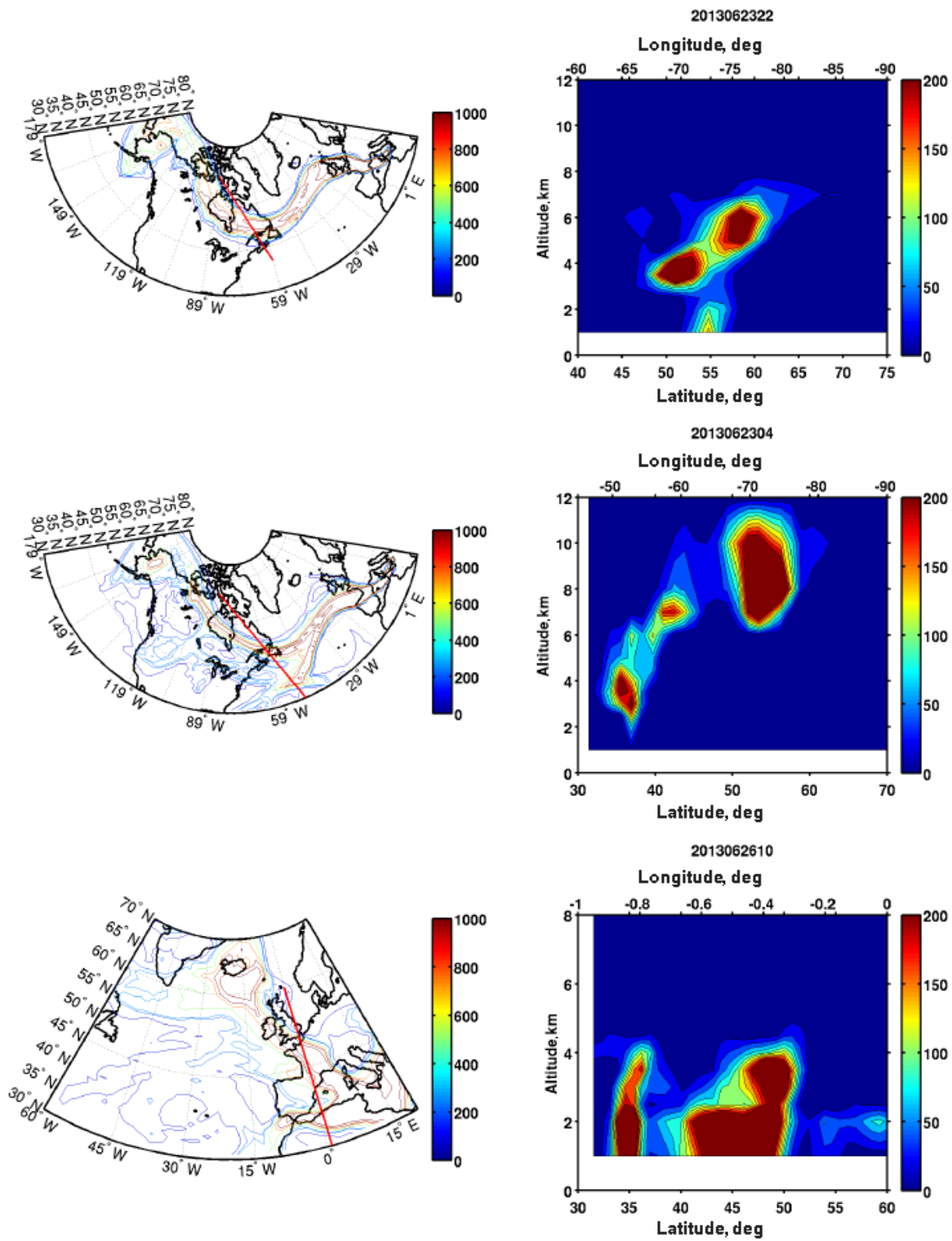

Figure 13. Same as Fig. 12 for the three aerosol layers identified by the Falcon 20 lidar on 28 June 2013: layer A (top), layer B (middle), and layer C (bottom).

nental origin, two areas are distinguished for the Colorado and Canadian fires using the results of the FLEXPART forward simulations. The Canadian fires significantly contribute to the AOD observed by MODIS over the Mediterranean Sea. The additional contribution of the upper aerosol layers of type III where the BB is mixed with dust also explains the significant AOD increase over the western Mediterranean region. The $\mathrm{BB}$ contribution to AOD is as large as the northern African dust contribution (type IV) that dominates the southern part of the domain with AOD values in the same range of 0.3-0.4 over northeastern Algeria and Tunisia.

\section{Conclusions}

A very interesting event of long-range transport of biomass burning (BB) aerosols between North America and the western Mediterranean region that took place in late June 2013 was documented during the ChArMEX/ADRIMED campaign. Although the occurrence of such events has been discussed in previous publications, the contribution of this work takes advantage of a large number of ground-based and airborne lidar measurements used in conjunction with spaceborne lidar observations by CALIOP during this period. A detailed analysis of the biomass burning North American sources was conducted including the assessment of 


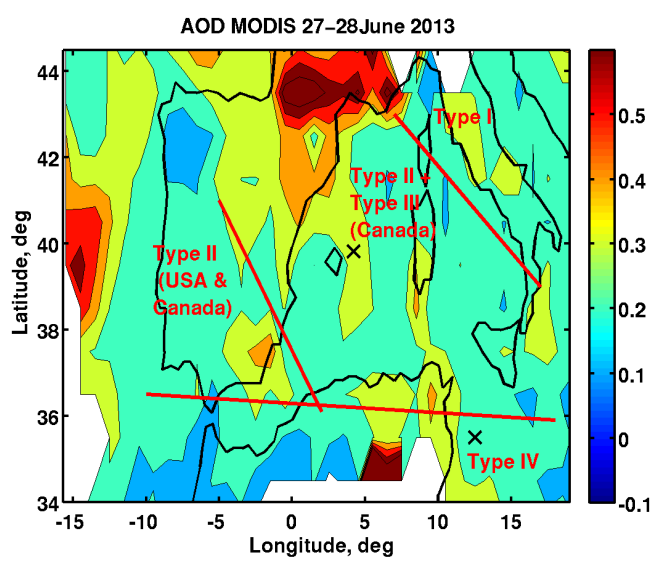

Figure 14. MODIS AOD horizontal distribution on 27 and 28 June 2013 over the Mediterranean region. The area corresponding to the aerosol types identified during our analysis of the BB plume passage is delimited by the red lines. The black crosses are for the Minorca and Lampedusa stations.

their transport to Europe using forward simulations with the FLEXPART model initialized using satellite observations. The specific question of mixing between dust and BB particles was addressed by considering the possible dust sources transported along the same transport pathway. The role of mixing was quantified by considering the optical properties of the different aerosol layers observed during two days of the ChArMEx campaign (27 and 28 June 2013) when the biomass burning aerosol load was at its maximum over the western Mediterranean. The three-dimensional structure of the aerosol distribution revealed by the lidar network and the airborne lidar flight provides a detailed assessment of the different aerosol source contributions when it is coupled with the results of the Lagrangian FLEXPART transport model. Four aerosol types were identified using the depolarization ratio and the three-dimensional structure of the aerosol plume: (i) pure BB layer, (ii) weakly dusty BB, (iii) a significant mixture of $\mathrm{BB}$ and dust transported from the North Atlantic trade wind region, and (IV) the direct northward outflow by the subtropical jet of Saharan dust not mixed with BB aerosol. Mixing of dust and BB can correspond to a 20-30\% dust contribution in the total aerosol backscatter. The comparison with the MODIS AOD distribution during this episode over the western Mediterranean Sea shows that the Canadian fire contributions were surprisingly as large as the direct northward dust outflow from the Sahara. An additional contribution from a mid-tropospheric aerosol layer due a mixture of dust and BB aerosol was found in the region of higher AOD seen by MODIS. The next step will now concern the use of all presented and analyzed data for evaluating 3-D regional models to simulate this specific event, in terms of optical properties, possible mixing and vertical extent of mineral dust and forest fire aerosol layers.
Acknowledgements. This work was funded by the French MISTRALS program funded by CNRS/INSU, ADEME, CEA, Météo-France and CNES for aerosol and cloud satellite mission validation. The NILU team led by A. Stohl is gratefully acknowledged for distributing the FLEXPART model. The SAFIRE team, INSU DT and D. Bruneau from LATMOS are gratefully acknowledged for the aircraft flight operation and the LNG lidar operation. The lidar measurements in Barcelona were supported by the 7th Framework Programme project Aerosols, Clouds, and Trace Gases Research Infrastructure Network (ACTRIS) (grant agreement no. 262254) and by the Spanish Ministry of Science and Innovation and FEDER funds under the projects TEC2012-34575, UNPC10-4E-442 and CGL2011-13580-E/CLI.

Edited by: O. Dubovik

\section{References}

Adler, G., Flores, J. M., Abo Riziq, A., Borrmann, S., and Rudich, Y.: Chemical, physical, and optical evolution of biomass burning aerosols: a case study, Atmos. Chem. Phys., 11, 1491-1503, doi:10.5194/acp-11-1491-2011, 2011.

Ancellet, G., Pelon, J., Blanchard, Y., Quennehen, B., Bazureau, A., Law, K. S., and Schwarzenboeck, A.: Transport of aerosol to the Arctic: analysis of CALIOP and French aircraft data during the spring 2008 POLARCAT campaign, Atmos. Chem. Phys., 14, 8235-8254, doi:10.5194/acp-14-8235-2014, 2014.

Bougiatioti, A., Stavroulas, I., Kostenidou, E., Zarmpas, P., Theodosi, C., Kouvarakis, G., Canonaco, F., Prévôt, A. S. H., Nenes, A., Pandis, S. N., and Mihalopoulos, N.: Processing of biomassburning aerosol in the eastern Mediterranean during summertime, Atmos. Chem. Phys., 14, 4793-4807, doi:10.5194/acp-144793-2014, 2014.

Brahney, J., Ballantyne, A., Sievers, C., and Neff, J.: Increasing $\mathrm{Ca}^{2+}$ deposition in the western US: The role of mineral aerosols, Aeolian Res., 10, 77-87, doi:10.1016/j.aeolia.2013.04.003, 2013.

Burton, S. P., Ferrare, R. A., Hostetler, C. A., Hair, J. W., Rogers, R. R., Obland, M. D., Butler, C. F., Cook, A. L., Harper, D. B., and Froyd, K. D.: Aerosol classification using airborne High Spectral Resolution Lidar measurements - methodology and examples, Atmos. Meas. Tech., 5, 73-98, doi:10.5194/amt-5-73-2012, 2012.

Cattrall, C., Reagan, J., Thome, K., and Dubovik, O.: Variability of aerosol and spectral lidar and backscatter and extinction ratios of key aerosol types derived from selected Aerosol Robotic Network locations, J. Geophys. Res., 110, D10S11, doi:10.1029/2004JD005124, 2005.

Chazette, P., Dabas, A., Sanak, J., Lardier, M., and Royer, P.: French airborne lidar measurements for Eyjafjallajökull ash plume survey, Atmos. Chem. Phys., 12, 7059-7072, doi:10.5194/acp-127059-2012, 2012.

Chazette, P., Marnas, F., and Totems, J.: The mobile Water vapor Aerosol Raman LIdar and its implication in the framework of the HyMeX and ChArMEx programs: application to a dust transport process, Atmos. Meas. Tech., 7, 1629-1647, doi:10.5194/amt-71629-2014, 2014. 
Chazette, P., Totems, J., Ancellet, G., Pelon, J., and Sicard, M.: Temporal consistency of lidar observations during aerosol transport events in the framework of the ChArMEx/ADRIMED campaign at Minorca in June 2013, Atmos. Chem. Phys., 16, 28632875, doi:10.5194/acp-16-2863-2016, 2016.

CIFFC: Canadian Interagency Forest Fire Center Inc. Report 2013, Tech. rep., available at: http://cwfis.cfs.nrcan.gc.ca/report/ archives? year $=2013 \&$ month $=06 \&$ day $=26 \&$ process $=$ Submit (last access: 13 April 2016), 2013.

Colorado HSEM: Homeland Security and Emergency Management: Colorado Wildfire Report, 26 June 2013, Tech. rep., available at: http://www.coemergency.com/2013/06/ colorado-wildfire-report-june-26-cofire.html (last access: 13 April 2016), 2013.

Di Iorio, T., di Sarra, A., Sferlazzo, D. M., Cacciani, M., Meloni, D., Monteleone, F., Fuá, D., and Fiocco, G.: Seasonal evolution of the tropospheric aerosol vertical profile in the central Mediterranean and role of desert dust, J. Geophys. Res.-Atmos., 114, D02201, doi:10.1029/2008JD010593, 2009.

Eck, T. F., Holben, B. N., Reid, J. S., Sinyuk, A., Hyer, E. J., O’Neill, N. T., Shaw, G. E., Vande Castle, J. R., Chapin, F. S., Dubovik, O., Smirnov, A., Vermote, E., Schafer, J. S., Giles, D., Slutsker, I., Sorokine, M., and Newcomb, W. W.: Optical properties of boreal region biomass burning aerosols in central Alaska and seasonal variation of aerosol optical depth at an Arctic coastal site, J. Geophys. Res.-Atmos., 114, D11201, doi:10.1029/2008JD010870, 2009.

Fernald, F. G.: Analysis of atmospheric lidar observations: some comments, Appl. Optics, 23, 652-653, doi:10.1364/AO.23.000652, 1984.

Fiebig, M., Stohl, A., Wendisch, M., Eckhardt, S., and Petzold, A.: Dependence of solar radiative forcing of forest fire aerosol on ageing and state of mixture, Atmos. Chem. Phys., 3, 881-891, doi:10.5194/acp-3-881-2003, 2003.

Flannigan, M., Stocks, B., Turetsky, M., and Wotton, M.: Impacts of climate change on fire activity and fire management in the circumboreal forest, Glob. Change Biol., 15, 549-560, doi:10.1111/j.1365-2486.2008.01660.x, 2009.

Formenti, P., Boucher, O., Reiner, T., Sprung, D., Andreae, M. O., Wendisch, M., Wex, H., Kindred, D., Tzortziou, M., Vasaras, A., and Zerefos, C.: STAAARTE-MED 1998 summer airborne measurements over the Aegean Sea 2. Aerosol scattering and absorption, and radiative calculations, J. Geophys. Res.-Atmos., 107, 4451, doi:10.1029/2001JD001536, 2002.

Forster, C., Wandinger, U., Wotawa, G., James, P., Mattis, I., Althausen, D., Simmonds, P., O’Doherty, S., Jennings, S. G., Kleefeld, C., Schneider, J., Trickl, T., Kreipl, S., Jäger, H., and Stohl, A.: Transport of boreal forest fire emissions from Canada to Europe, J. Geophys. Res.-Atmos., 106, 22887-22906, doi:10.1029/2001JD900115, 2001.

Generoso, S., Bréon, F.-M., Balkanski, Y., Boucher, O., and Schulz, M.: Improving the seasonal cycle and interannual variations of biomass burning aerosol sources, Atmos. Chem. Phys., 3, 12111222, doi:10.5194/acp-3-1211-2003, 2003.

Ginoux, P., Chin, M., Tegen, I., Prospero, J. M., Holben, B., Dubovik, O., and Lin, S.-J.: Sources and distributions of dust aerosols simulated with the GOCART model, J. Geophys. Res.Atmos., 106, 20255-20273, doi:10.1029/2000JD000053, 2001.
Gross, S., Tesche, M., Freudenthaler, V., Toledano, C., Wiegner, M., Ansmann, A., Althausen, D., and Seefeldner, M.: Characterization of Saharan dust, marine aerosols and mixtures of biomassburning aerosols and dust by means of multi-wavelength depolarization and Raman lidar measurements during SAMUM 2, Tellus B, 63, 706-724, doi:10.1111/j.1600-0889.2011.00556.x, 2011.

Gross, S., Geiss, A., Heimerl, K., Gasteiger, J., Freudenthaler, V., Weinzier, B., and Wiegner, M.: Characterization of long-range transported Canadian biomass burning over Central Europe - A case study, Geophys. Res. Abstr., 2561, EGU General Assembly 2015, Vienna, Austria, 2015.

Guieu, C., Ridame, C., Pulido-Villena, E., Bressac, M., Desboeufs, K., and Dulac, F.: Impact of dust deposition on carbon budget: a tentative assessment from a mesocosm approach, Biogeosciences, 11, 5621-5635, doi:10.5194/bg-11-5621-2014, 2014.

Hahnenberger, M. and Nicoll, K.: Meteorological characteristics of dust storm events in the eastern Great Basin of Utah, U.S.A., Atmos. Environ., 60, 601-612, doi:10.1016/j.atmosenv.2012.06.029, 2012.

Kumar, D., Rocadenbosch, F., Sicard, M., Comeron, C., Munoz, C., Lange, D., Tomas, S., and Gregorio, E.: Six-channel polychromator design and implementation for the UPC elasticRaman LIDAR, in: SPIE Remote Sensing, 81820, International Society for Optics and Photonics, Prague, Czech Republic, 2011.

Liousse, C., Devaux, C., Dulac, F., and Cachier, H.: Aging of savanna biomass burning aerosols: Consequences on their optical properties, J. Atmos. Chem., 22, 1-17, doi:10.1007/BF00708178, 1995.

Liu, Y., Goodrick, S., and Heilman, W.: Wildland fire emissions, carbon, and climate: Wildfire-climate interactions, Forest Ecol Manag., 317, 80-96, doi:10.1016/j.foreco.2013.02.020, 2014.

Mallet, M., Dulac, F., Formenti, P., Nabat, P., Sciare, J., Roberts, G., Pelon, J., Ancellet, G., Tanré, D., Parol, F., Denjean, C., Brogniez, G., di Sarra, A., Alados-Arboledas, L., Arndt, J., Auriol, F., Blarel, L., Bourrianne, T., Chazette, P., Chevaillier, S., Claeys, M., D’Anna, B., Derimian, Y., Desboeufs, K., Di Iorio, T., Doussin, J.-F., Durand, P., Féron, A., Freney, E., Gaimoz, C., Goloub, P., Gómez-Amo, J. L., Granados-Muñoz, M. J., Grand, N., Hamonou, E., Jankowiak, I., Jeannot, M., Léon, J.-F., Maillé, M., Mailler, S., Meloni, D., Menut, L., Momboisse, G., Nicolas, J., Podvin, T., Pont, V., Rea, G., Renard, J.-B., Roblou, L., Schepanski, K., Schwarzenboeck, A., Sellegri, K., Sicard, M., Solmon, F., Somot, S., Torres, B., Totems, J., Triquet, S., Verdier, N., Verwaerde, C., Waquet, F., Wenger, J., and Zapf, P.: Overview of the Chemistry-Aerosol Mediterranean Experiment/Aerosol Direct Radiative Forcing on the Mediterranean Climate (ChArMEx/ADRIMED) summer 2013 campaign, Atmos. Chem. Phys., 16, 455-504, doi:10.5194/acp-16-455-2016, 2016.

Müller, D., Mattis, I., Wandinger, U., Ansmann, A., Althausen, D., and Stohl, A.: Raman lidar observations of aged Siberian and Canadian forest fire smoke in the free troposphere over Germany in 2003: Microphysical particle characterization, J. Geophys. Res.-Atmos., 110, doi:10.1029/2004JD005756, 2005.

Müller, D., Mattis, I., Ansmann, A., Wandinger, U., Ritter, C., and Kaiser, D.: Multiwavelength Raman lidar observations of particle growth during long-range transport of forest-fire smoke in the free troposphere, Geophys. Res. Lett., 34, L05803, doi:10.1029/2006GL027936, 2007. 
Nisantzi, A., Mamouri, R. E., Ansmann, A., and Hadjimitsis, D.: Injection of mineral dust into the free troposphere during fire events observed with polarization lidar at Limassol, Cyprus, Atmos. Chem. Phys., 14, 12155-12165, doi:10.5194/acp-1412155-2014, 2014.

Omar, A., Winker, D., Kittaka, C., Vaughan, M., Liu, Z., Hu, Y., Trepte, C., Rogers, R., Ferrare, R., Lee, K., Kuehn, R., and Hostetler, C.: The CALIPSO Automated Aerosol Classification and Lidar Ratio Selection Algorithm, J. Atmos. Ocean. Tech., 26, 1994-2014, doi:10.1175/2009JTECHA1231.1, 2009.

Paris, R., Desboeufs, K. V., Formenti, P., Nava, S., and Chou, C.: Chemical characterisation of iron in dust and biomass burning aerosols during AMMA-SOP0/DABEX: implication for iron solubility, Atmos. Chem. Phys., 10, 4273-4282, doi:10.5194/acp10-4273-2010, 2010.

Pelon, J., Flamant, C., Chazette, P., Leon, J.-F., Tanre, D., Sicard, M., and Satheesh, S. K.: Characterization of aerosol spatial distribution and optical properties over the Indian Ocean from airborne LIDAR and radiometry during INDOEX' 99, J. Geophys. Res.-Atmos., 107, 8029, doi:10.1029/2001JD000402, 2002.

Pelon, J., Ancellet, G., Chazette, P., Totems, J., Sicard, M., Dulac, F., Di Ioro, T., Formenti, P., and Mallet, M.: Lagrangian analysis of forest fire aerosol emissions from North America to Western Mediterranean basin during the CHARMEX 2013 summer campaign, Geophys. Res. Abstr., EGU2015-11710, EGU General Assembly 2015, Vienna, Austria, 2015.

Pelon, J., Ancellet, G., Totems, J., Denjean, C., Formenti, P., Chazette, P., Dulac, F., Mallet, M., Di Iorio, T., and Sicard, M.: Characterization of radiative properties of Long-range transported biomass burning aerosols over the western Mediterranean basin during ADRIMED-CHARMEX using airborne, groundbased and satellite observations, in preparation, 2016.

Petzold, A., Weinzierl, B., Huntrieser, H., Stohl, A., Real, E., Cozic, J., Fiebig, M., Hendricks, J., Lauer, A., Law, K., Roiger, A., Schlager, H., and Weingartner, E.: Perturbation of the European free troposphere aerosol by North American forest fire plumes during the ICARTT-ITOP experiment in summer 2004, Atmos. Chem. Phys., 7, 5105-5127, doi:10.5194/acp-7-51052007, 2007.

Ruiz-Arias, J. A., Dudhia, J., Gueymard, C. A., and Pozo-Vázquez, D.: Assessment of the Level-3 MODIS daily aerosol optical depth in the context of surface solar radiation and numerical weather modeling, Atmos. Chem. Phys., 13, 675-692, doi:10.5194/acp-13-675-2013, 2013.

Schnaiter, M., Linke, C., Müller, O., Naumann, K.-H., Saathoff, H., Wagner, R., Schurath, U., and Wehner, B.: Absorption amplification of black carbon internally mixed with secondary organic aerosol, J. Geophys. Res.-Atmos., 110, D19204, doi:10.1029/2005JD006046, 2005.

Sciare, J., Oikonomou, K., Favez, O., Liakakou, E., Markaki, Z., Cachier, H., and Mihalopoulos, N.: Long-term measurements of carbonaceous aerosols in the Eastern Mediterranean: evidence of long-range transport of biomass burning, Atmos. Chem. Phys., 8, 5551-5563, doi:10.5194/acp-8-5551-2008, 2008.
Stohl, A., Eckhardt, S., Forster, C., James, P., Spichtinger, N., and Seibert, P.: A replacement for simple back trajectory calculations in the interpretation of atmospheric trace substance measurements, Atmos. Environ., 36, 4635-4648, doi:10.1016/S13522310(02)00416-8, 2002.

Tesche, M., Ansmann, A., Müller, D., Althausen, D., Engelmann, R., Freudenthaler, V., and Gross, S.: Vertically resolved separation of dust and smoke over Cape Verde using multiwavelength Raman and polarization lidars during Saharan Mineral Dust Experiment 2008, J. Geophys. Res.-Atmos., 114, D13202, doi:10.1029/2009JD011862, 2009.

Vaughan, M. A., Powell, K. A., Winker, D. M., Hostetler, C. A., Kuehn, R. E., Hunt, W. H., Getzewich, B. J., Young, S. A., Liu, Z., and McGill, M. J.: Fully Automated Detection of Cloud and Aerosol Layers in the CALIPSO Lidar Measurements, J. Atmos. Ocean. Tech., 26, 2034-2050, doi:10.1175/2009JTECHA1228.1, 2009.

Vaughan, M. A., Garnier, A., Liu, Z., Josset, D., Hu, Y., Lee, K.P., Hunt, W., Vernier, J.-P., Rodier, S., Pelon, J., and Winker, D.: Chaos, consternation and CALIPSO calibration: new strategies for calibrating the CALIOP $1064 \mathrm{~nm}$ Channel, in: Proceedings of the 26th Int. Laser Radar Conf., Porto Heli, Greece, 39-55, Alexandros Papayannis, University of Athens, Greece, 2012.

Warneke, C., Bahreini, R., Brioude, J., Brock, C., de Gouw, J., Fahey, D., Froyd, K., Holloway, J., Middlebrook, A., Miller, L., Montzka, S., Murphy, D., Peischl, J., Ryerson, T., Schwarz, J., Spackman, J., and Veres, P.: Biomass burning in Siberia and Kazakhstan as an important source for haze over the Alaskan Arctic in April 2008, Geophys. Res. Lett., 36, L02813, doi:10.1029/2008GL036194, 2009.

Warneke, C., Froyd, K. D., Brioude, J., Bahreini, R., Brock, C. A., Cozic, J., de Gouw, J. A., Fahey, D. W., Ferrare, R., Holloway, J. S., Middlebrook, A. M., Miller, L., Montzka, S., Schwarz, J. P., Sodemann, H., Spackman, J. R., and Stohl, A.: An important contribution to springtime Arctic aerosol from biomass burning in Russia, Geophys. Res. Lett., 37, L01801, doi:10.1029/2009GL041816, 2010.

Winker, D. M., Vaughan, M. A., Omar, A., Hu, Y., Powell, K. A., Liu, Z., Hunt, W. H., and Young, S. A.: Overview of the CALIPSO Mission and CALIOP Data Processing Algorithms, J. Atmos. Ocean. Tech., 26, 2310-2323, doi:10.1175/2009JTECHA1281.1, 2009.

Young, S. A.: Analysis of lidar backscatter profiles in optically thin clouds, Appl. Optics, 34, 7019-7031, doi:10.1364/AO.34.007019, 1995. 